\title{
Željezničke prometnice u obalnom pojasu Nezavisne Države Hrvatske do kapitulacije Kraljevine Italije
}

\author{
NIKICA BARIĆ \\ Hrvatski institut za povijest \\ Zagreb, Hrvatska \\ nbaric@isp.hr
}

\begin{abstract}
U članku se, znatnim dijelom na temelju novih arhivskih izvora, prikazuje stanje željezničkih prometnica u obalnom pojasu Nezavisne Države Hrvatske. Talijanska vojska preuzela je početkom rujna 1941. upravu u tom pojasu. Članak prati stanje na tim prometnicima do talijanske kapitulacije u rujnu 1943. godine. Kroz ovo istraživanje može se doći do određenih novih spoznaja o odnosima Nezavisne Države Hrvatske i Kraljevine Italije, ali i do novih spoznaja kada je riječ o prometnim vezama, u konkretnom slučaju željezničkim, koje su u ratnim okolnostima povezivale krajeve uz jadransku obalu sa zaleđem, odnosno Zagrebom i drugim krajevima sjeverno od rijeke Save.
\end{abstract}

Ključne riječi: Nezavisna Država Hrvatska; Ministarstvo prometa i javnih radova Nezavisne Države Hrvatske; Hrvatske državne željeznice; vojska Kraljevine Italije; željeznički promet

Uvod

Glavna istraživačka pitanja u ovom članku su: Koje su željezničke veze povezivale obalni pojas Nezavisne Države Hrvatske (NDH) sa Zagrebom i ostalim dijelovima države? Koji su čimbenici utjecali na djelomične, pa i potpune prekide tih željezničkih prometnica? Kako je željeznički promet u obalnom pojasu NDH djelovao s obzirom na činjenicu da je vojska Kraljevine Italije početkom rujna 1941. preuzela upravu nad obalnim pojasom NDH? Na ta ću pitanja odgovoriti prateći stanje do talijanske kapitulacije u rujnu 1943. godine.

Smatram da odgovori na postavljena pitanja mogu dovesti do novih spoznaja o stanju prometnih veza u NDH i pokazati koji su čimbenici utjecali na prijevoz roba i pokretljivost ljudi u ratnim okolnostima. Navedena tema $\mathrm{u}$ ovom je članku usredotočena na pitanje prometne povezanosti krajeva uz Jadran s krajevima sjeverno od Save. To, smatram, može biti korisno i za obradu nekih drugih tema, primjerice problema opskrbe stanovništva hranom u 
ratnim okolnostima, budući da je obalni pojas NDH znatnim dijelom ovisio o dopremi hrane upravo iz područja sjeverno od Save.

Rimskim ugovorima od 18. svibnja 1941. određena je granica između Kraljevine Italije i NDH. Nakon izbijanja ustanka protiv NDH u ljeto te godine talijanska je vojska 7. rujna 1941. preuzela zapovjedništvo nad upravnim vlastima NDH i njezinim postrojbama u tzv. Razvojačenom pojasu. Postojanje toga pojasa određeno je Rimskim ugovorima, a on se prostirao kroz priobalni dio NDH, od Gorskoga kotara preko Hrvatskoga primorja do Like, dijelova Dalmacije koji su nakon Rimskih ugovora ostali u sastavu NDH i dijelova jugozapadne Bosne i Hercegovine. Tijekom listopada 1941. talijanske snage zaposjele su i područje između Razvojačenoga pojasa i njemačko-talijanske demarkacijske crte koja se protezala kroz NDH. ${ }^{1}$

Kada je riječ o pojmovima, područja koja su Talijani anektirali Rimskim ugovorima nazivana su „Prvom zonom”, Razvojačeni odnosno obalni pojas NDH nazivan je „Drugom zonom”, a područje između Razvojačenoga pojasa i njemačko-talijanske demarkacijske crte nazivano je „Trećom zonom”.

Talijanske postrojbe u NDH bile su u sastavu 2. talijanske armije, čiji se stožer nalazio u Sušaku. Ta je armija jedno vrijeme nosila ime „Više zapovjedništvo oružanih snaga Slovenija-Dalmacija”. Da bi se uskladilo djelovanje vlasti $\mathrm{NDH}$ i talijanske vojske u Razvojačenom pojasu, osnovano je Opće upravno povjereništvo NDH, čije je sjedište također bilo u Sušaku. ${ }^{2}$

Hrvatske državne željeznice (HDŽ) imale su ravnateljstva u Zagrebu i Sarajevu. Nalazile su se pod upravom Ministarstva prometa i javnih radova NDH. Od listopada 1942. do prosinca 1943. javni radovi izdvojeni su iz Ministarstva prometa i premješteni u sastav Ministarstva unutarnjih poslova NDH, a zatim su ponovno vraćeni u sastav Ministarstva prometa. U okviru Ministarstva prometa za željeznički je promet bio zadužen Odjel za željeznice, autopromet i brodarstvo, a od listopada 1942. Glavno ravnateljstvo za promet. ${ }^{3}$

Sporazum talijanske vojske i Nezavisne Države Hrvatske o željezničkom prometu u Razvojačenom pojasu

Već krajem srpnja 1941., neposredno nakon izbijanja ustanka protiv NDH u jugozapadnoj Bosni, Lici i sjevernoj Dalmaciji, talijanska vojska odlučila je preuzeti osiguranje željezničkih pruga, koje su za njih bile važne jer su povezivale matični talijanski teritorij s dijelovima Dalmacije koje su

\footnotetext{
1 LEKOVIĆ, „Reagovanje Italijana na ustanak u Bosni i Hercegovini”, 466-484; BARIĆ, Ustroj kopnene vojske domobranstva NDH, 310-316.

2 LEKOVIĆ, „Reagovanje Italijana na ustanak u Bosni i Hercegovini”, 476; BARIĆ, Ustroj kopnene vojske domobranstva NDH, 315.

3 Opširnije o ustroju HDŽ-a vidi: LAJNERT, „Ustroj Hrvatskih državnih željeznica”, 101129.
} 
Talijani anektirali Rimskim ugovorima (pruga Rijeka - Ogulin - Gospić Knin - Split). ${ }^{4}$

U Zagrebu je 26. kolovoza 1941. održan sastanak talijanskih predstavnika s visokim dužnosnicima NDH, gdje je razmatrano kako će talijanska vojska preuzeti upravu u Razvojačenom pojasu. U vezi s prometom na željezničkoj pruzi od Rijeke do Splita talijanski predstavnici istaknuli su da će oni držati „upravu” nad prugom, a HDŽ je na njoj trebao obavljati administrativne poslove i brinuti se za njezino održavanje. ${ }^{5}$

Nedugo nakon što je talijanska 2. armija 7. rujna 1941. objavila da preuzima upravu u Razvojačenom pojasu, u Zagrebu su 17. rujna državni tajnik za željeznički promet Josip Marković i talijanski predstavnici sklopili sporazum o organizaciji željezničkoga prometa u Razvojačenom pojasu. Dogovoreno je da će od 5. listopada pruge Sušak - Ogulin - Split, Šibenik - Perković-Slivno, Split - Sinj i Knin - Drvar prijeći pod nadzor Zapovjedništva 2. talijanske armije. Pri Zapovjedništvu 2. armije trebalo je osnovati Izaslanstvo za vojne transporte popunjeno talijanskim vojnim osobljem i službenicima Talijanskih državnih željeznica. To izaslanstvo trebalo je upravljati prometom na spomenutim prugama. U Sušaku je trebalo osnovati i Inspektorat HDŽ-a, koji je na temelju naredbi Izaslanstva i uz pomoć osoblja HDŽ-a na prugama trebao na njima osigurati redovni promet. Pri Ravnateljstvu HDŽ-a u Zagrebu trebalo je osnovati talijanski ured za vezu, koji je trebao usklađivati odnose između Izaslanstva za vojne transporte u Sušaku i HDŽ-a. ${ }^{6}$
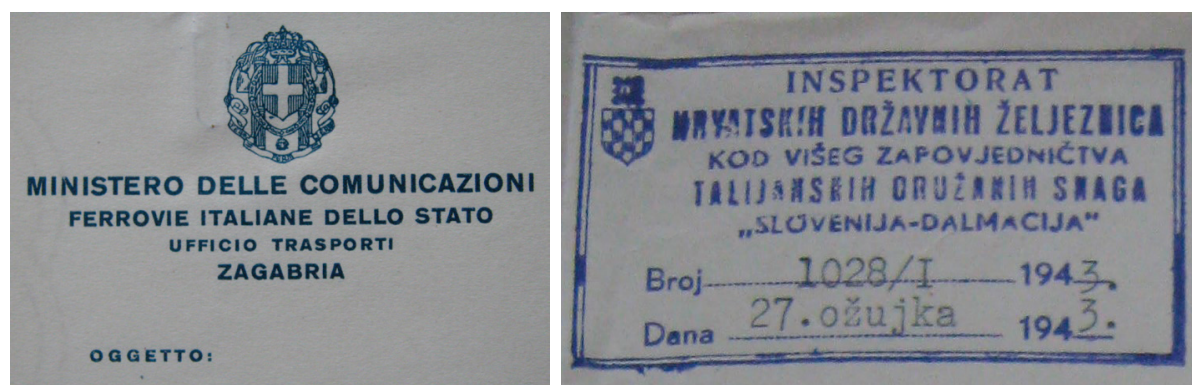

Slike: Zaglavlje dopisa Transportnog ureda Talijanskih državnih željeznica u Zagrebu (lijevo) i pečat Inspektorata HDŽ u Sušaku (desno).

Izaslanstvo za vojne transporte u Sušaku moglo je nad prugama nad kojima je imalo nadzor uspostaviti talijanska vojna i željeznička tijela, poput vojnih

${ }_{4}$ Zbornik dokumenata i podataka o NOR-u, tom XIII, knj. 1, dok. br. 89; BARIĆ, Ustroj kopnene vojske domobranstva NDH, 311.

5 Zbornik dokumenata i podataka o NOR-u, tom XIII, knj. 1, dok. br. 130.

6 HR-HDA-491-OUP, Broj: 2168/1941. 
zapovjedništava željezničkih postaja i stražarskih mjesta, a na tim je prugama moglo imati svoje inspektore i kontrolore. ${ }^{7}$

Inspektorat HDŽ-a u Sušaku trebao je početi djelovati 5. listopada 1941. godine. Na njegovu čelu bio je ing. Marin Novak. Obavještavajući o tome zainteresirane ustanove, Odjel za željeznice u Zagrebu objasnio je da se u svim pitanjima željezničkoga prometa u obalnom pojasu NDH, posebno kada je riječ o talijanskim vojnim transportima, treba obratiti Inspektoratu, kao i da se njegove naredbe i upute moraju u cijelosti izvršavati. ${ }^{8}$

Ipak se državni tajnik za željeznički promet Marković 19. siječnja 1942. obratio Općem upravnom povjereništvu NDH pri Zapovjedništvu 2. talijanske armije s prijedlogom da se Inspektorat HDŽ-a u Sušaku ukine. Marković je smatrao da bi njegove poslove moglo preuzeti Ravnateljstvo HDŽ-a u Zagrebu, jedan činovnik HDŽ-a u Sušaku i nekoliko činovnika koji bi bili smješteni u Ogulinu. Kada su 16. i 17. rujna 1941. u Zagrebu vođeni pregovori o uređenju željezničkoga prometa, predstavnici HDŽ-a upozoravali su Talijane da uspostava hrvatskoga željezničkog inspektorata neće koristiti ni HDŽ-u ni talijanskoj strani. Talijani su to odbacili jer su smatrali da će takav inspektorat moći udovoljiti svim njihovim potrebama bez sudjelovanja Ravnateljstva HDŽ-a u Zagrebu. Praksa je pokazala suprotno, odnosno da Inspektorat HDŽ-a u Sušaku može udovoljiti talijanskim potrebama samo ako se obrati Zagrebu. Uostalom, i talijansko Izaslanstvo za vojne transporte u Sušaku izravno se obraćalo Ravnateljstvu HDŽ-a u Zagrebu. Zato je Marković od Općega upravnog povjereništva zahtijevao da se Talijanima predloži ukidanje Inspektorata. ${ }^{9}$

Opće upravno povjereništvo NDH odgovorilo je Markoviću krajem siječnja, obavještavajući ga da je njegov prijedlog o ukidanju Inspektorata prenesen Zapovjedništvu 2. armije. Ipak je ocijenjeno da bi ukidanje Inspektorata bila pogreška jer bi bez njega Talijani dodatno povećali nadzor nad HDŽ-om u obalnom pojasu. Marković je odgovorio ponovno objašnjavajući da ukidanje Inspektorata HDŽ-a u Sušaku ne bi štetilo NDH. Naprotiv, ukidanjem toga tijela željeznički promet i osoblje u obalnom pojasu našli bi se pod boljim nadzorom Ravnateljstva HDŽ-a u Zagrebu. No, Zapovjedništvo 2. armije obavijestilo je 15. veljače 1942. Opće upravno povjereništvo da ne vidi smisao ukidanja Inspektorata HDŽ-a u Sušaku, nego bi tom tijelu trebalo osigurati „autonomiju” koja je i predviđena sporazumom sklopljenim 17. rujna 1941. u Zagrebu. ${ }^{10}$

Ubrzo se pojavilo i pitanje plaćanja talijanskih troškova prijevoza njihovih vojnika i vojnih transporta na prugama HDŽ-a. Kada je sporazumom od 17. rujna 1941. uređeno pitanje željezničkoga prometa u Razvojačenom pojasu, odnosno na području pod upravom talijanske vojske, određeno je da će pitanje troškova prijevoza talijanske vojske biti riješeno sporazumom vlada NDH

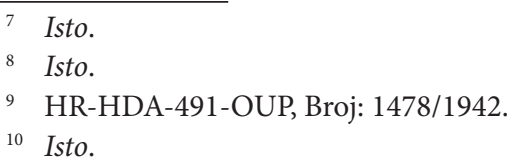


i Kraljevine Italije. No, u ožujku 1942. talijanski predstavnici izjavili su da se plaćanje konačnih troškova prijevoza njihove vojske u NDH treba razmotriti tek nakon „svršetka rata”. Ministarstvo prometa NDH obratilo se u vezi s time početkom srpnja 1942. Općem upravnom povjereništvu u Sušaku, ocjenjujući da je neprihvatljivo da gospodarski mnogo snažnija država poput Italije na taj način izbjegava podmiriti svoje troškove HDŽ-u. Pritom je istaknuto da je, suprotno Talijanima, njemačka vojska odmah isplatila akontaciju u iznosu od 2 milijuna Reichsmaraka za prijevoz svojih transporta na prugama u NDH. Ministarstvo prometa objasnilo je da će zbog opisane situacije od sredine srpnja 1942. morati prekinuti sav promet za potrebe talijanske vojske, tražeći od Općega upravnog povjereništva da intervenira kod Zapovjedništva 2. armije da se to pitanje riješi. ${ }^{11}$

Razumljivo, HDŽ nije prestao prevoziti za potrebe talijanske vojske, ali nije jasno je li taj problem naposljetku riješen u korist NDH. Sredinom 1942. u Mađarskoj je održana konferencija predstavnika željeznica osovinskih zemalja. Tom prilikom uređeno je i pitanje željezničkoga prijevoza za potrebe vojska sila Osovine na željeznicama u NDH. Ipak je HDŽ i prema kraju 1942. imao problema kada je od Talijana zahtijevao poštovanje dogovora postignutog u Mađarskoj. ${ }^{12}$ Talijanska nespremnost za podmirivanje troškova prijevoza vlastitih snaga na prugama HDŽ-a bila je samo još jedan primjer kako je Kraljevina Italija, koristeći svoju premoć, crpila gospodarske i druge izvore $\mathrm{NDH}$ i pritom njezine vlasti stavljala u podređeni i nepovoljni gospodarskofinancijski položaj. ${ }^{13}$

Promjene nakon sklapanja Zagrebačkoga sporazuma 19. lipnja 1942. godine

U ljeto i jesen 1941. talijanska vojska širila je svoju prisutnost na području NDH. Nasuprot tome, tijekom 1942. Talijani su započeli s povlačenjem iz dijelova NDH. Tako je 19. lipnja te godine sklopljen Zagrebački sporazum o povlačenju talijanske vojske iz Treće zone, osim s područja Karlovca, a zatim i iz dijelova Razvojačenoga pojasa. Talijani su pri preuzimanju uprave nad Razvojačenim pojasom u ljeto 1941. zahtijevali da se s toga područja povuče većina domobranskih snaga i sve postrojbe Ustaške vojnice. Za razliku od toga, Zagrebački sporazum podrazumijevao je da postrojbe NDH zamijene talijanske snage na područjima s kojih će se one povući. I prema kraju 1942. plan talijanske vojske bio je nastaviti smanjivati svoju prisutnost u NDH, ograničavajući se na zaštitu područja anektiranih 1941. i zadržavajući svoje snage uglavnom u dijelovima NDH koji su činili neposredno zaleđe anektiranih krajeva. ${ }^{14}$

11 HR-HDA-491-OUP, Broj: 7263/1942.

12 HR-HDA-491-OUP, Broj: 10.662/1942., Broj: 13.010/1942.

13 Opširnije o talijanskom iskorištavanju gospodarskih i financijskih izvora NDH vidi: KISIĆ KOLANOVIĆ, NDH i Italija, 237-247.

14 NENEZIĆ, Jugoslovenske oblasti pod Italijom, 111-123; BARIĆ, Ustroj kopnene vojske domobranstva NDH, 317-329. 
Što se tiče željezničkoga prometa, Zagrebačkim sporazumom predviđeno je da će postrojbe NDH, koje će biti pod talijanskim zapovjedništvom, preuzeti čuvanje željezničkih pruga Karlovac - Ogulin, Ogulin - Knin i Konjic - Mostar, pri čemu je talijanska vojska trebala zadržati osiguranje u Kninu, Mostaru i Ogulinu. ${ }^{15}$

Krajem srpnja 1942. Zapovjedništvo 2. armije ocijenilo je da mora i dalje osiguravati spomenute željezničke linije svojim snagama budući da NDH nije ispunila obvezu osiguranja tih prometnica. ${ }^{16}$ Do sredine kolovoza 1942. stanje se djelomično promijenilo, odnosno domobranstvo je uz pomoć talijanske vojske počelo ustrojavati domobranske željezničke stražarske bojne koje su trebale preuzeti osiguranje željeznica u obalnom pojasu. ${ }^{17}$ Tijekom druge polovine 1942. u Ogulinu je osnovano Zapovjedništvo osiguranja željezničke mreže „Lika”, koje je pod svojim zapovjedništvom imalo tri domobranske željezničke stražarske bojne, u čijem je ustrojavanju pomogla i talijanska vojska. ${ }^{18} \mathrm{U}$ Ogulin je raspoređena i jedna satnija Prometnih zdrugova Ustaške vojnice, ustaških postrojbi zaduženih za osiguranje željezničkoga prometa. ${ }^{19}$

\section{Pruga Zagreb - Rijeka}

Željeznička pruga Zagreb - Rijeka bila je važna za Talijane jer se njome dopremala nafta iz Rumunjske za Italiju. Nafta se iz Beograda i Vukovara željeznicom prevozila do Zagreba, a zatim do Rijeke. ${ }^{20}$

Ta je pruga, kao uostalom i druge u NDH, ubrzo postala meta napada partizana. ${ }^{21}$ Primjerice, u ranim jutarnjim satima 19. travnja 1942. putnički vlak koji je iz Rijeke putovao prema Zagrebu naišao je u blizini željezničke postaje Gornje Dubrave na onesposobljenu prugu, pa je iskočio iz kolosijeka. O tome je Kotarska oblast u Ogulinu izvijestila:

„Lokomotiva se survala u jarak prevalivši se nekoliko puta i sobom povukla 6 osobnih vagona i jedna službena kola, što se sve zapalilo od lokomotive i zajedno s njom izgorilo. Strojovođa je odmah od opeklina umro, ložač teško ranjen prevežen je u bolnicu u Ogulinu, gdje je za kratko vrijeme umro. Od ostalih osoba, koje su se nalazile u vlaku, do sada je ustanovljeno, da imade 3 teško ranjenih i 4 lakše ranjenih. - Da li je još tko životom nastradao nije se moglo do

15 HR-HDA-219-MPJR NDH, Glavno ravnateljstvo za promet, V. T. Broj: 1/1942.; Zbornik dokumenata i podataka o NOR-u, tom V, knj. 32, dok. br. 116.

16 Zbornik dokumenata i podataka o NOR-u, tom XIII, knj. 2, dok. br. 81.

17 Zbornik dokumenata i podataka o NOR-u, tom XIII, knj. 2, dok. br. 90.

18 BARIĆ, Ustroj kopnene vojske domobranstva NDH, 168-171, 323.

19 MARIJAN, „Ustaške vojne postrojbe”, 40.

20 TOMASEVICH, War and Revolution in Yugoslavia, 629; HR-HDA-219-MPJR NDH, Glavno ravnateljstvo za promet, Taj. Broj: 950/1943.

21 Inspektorat HDŽ-a u Sušaku izradio je zanimljive grafičke prikaze intenziteta i vrsta napada na željezničku prugu Rijeka - Ogulin - Split koji su se dogodili krajem 1941. i u prvoj polovini 1942. godine. Vidi: HR-HDA-491-OUP, Broj: 7908/1942. 
sada ustanoviti pošto su vagoni na jednoj gomili, te još nisu rastavljeni odnosno odstranjeni. Kada se sve uredi onda će se točno znati, koliko imade žrtava. $\mathrm{Na}$ čišćenju se radi. Sva je sreća, da je bilo vrlo malo putnika u vlaku. Promet se vrši prelaženjem. Ima nade, da će se pruga danas očistiti." ${ }^{22}$

Napadi partizana na prugu su se nastavljali, pa su sredinom 1942. Talijani na njoj obustavili noćni promet. ${ }^{23}$ Zbog napada partizana na prugu do Rijeke transporti nafte za Italiju morali su biti preusmjeravani na prugu Zidani Most - Ljubljana. ${ }^{24}$ Do početka rujna 1942 . brojni napadi partizana na vlakove i diverzije na pruzi, posebno na području Generalskoga Stola, onemogućavali su redovni promet na pruzi Zagreb - Rijeka. Nakon pojedinih napada promet je bio prekinut 15, 20 ili čak 50 sati. $^{25}$

O intenzitetu napada govori i jedan dopis predstavnika Talijanskih državnih željeznica u Rijeci s početka 1943. godine. U njemu stoji da je tijekom 1942. samo na dionici od Rijeke do Hrvatskih Moravica izvedeno više od „nekoliko stotina” napada partizana na prugu. U tim napadima onesposobljena je polovina lokomotiva HDŽ-a u Hrvatskim Moravicama, a od 350 vlakopratnih službenika HDŽ-a u Hrvatskim Moravicama poginulo ih je oko 40, a više od 100 teško je ranjeno. ${ }^{26}$

Talijanska je vojska željezničkim transportima nafte već u Zagrebu, odnosno Svetoj Klari, dodavala oklopne vagone i pratnju. Pritom su nastajali razni problemi, što je vodilo do poremećaja željezničkoga prometa na zagrebačkom području. Zato su predstavnici HDŽ-a krajem 1942. zahtijevali da Talijani prekinu postavljati osiguranje transportima nafte na prugama oko Zagreba. Hrvatske državne željeznice smatrale su da je pruga od Zagreba do Karlovca sigurna za promet, pa se predlagalo da talijanska vojska osigura transport nafte u Karlovcu. Do početka 1943. te su poteškoće ipak riješene. ${ }^{27}$

Kao što je rečeno, Zagrebačkim sporazumom od 19. lipnja 1942. dogovoreno je povlačenje talijanske vojske iz cijele Treće zone, s iznimkom područja Karlovca. Odande se Talijani nisu povukli jer su i ondje željeli osiguravati željezničku prugu do Rijeke. ${ }^{28}$ Glavni stožer talijanske kopnene vojske odredio je u travnju 1943. da talijanske postrojbe moraju ustrojiti obrambenu crtu Jastrebarsko - Vrbovsko - Delnice - morska obala, kojom je trebalo zaštititi i željezničku prugu od Karlovca do Rijeke. Na toj crti trebalo je podići betonske bunkere, postaviti pojaseve bodljikave žice i minska polja. ${ }^{29}$

\footnotetext{
22 HR-HDA-491-OUP, Broj: 4227/1942.

23 Zbornik dokumenata i podataka o NOR-u, tom XII, knj. 2, dok. br. 79.

24 Zbornik dokumenata i podataka o NOR-u, tom XII, knj. 2, dok. br. 94.

25 Zbornik dokumenata i podataka o NOR-u, tom XII, knj. 2, dok. br. 144.

26 HR-HDA-219-MPJR NDH, Glavno ravnateljstvo za promet, Taj. Broj: 618/1943.

27 HR-HDA-219-MPJR NDH, Glavno ravnateljstvo za promet, Taj. Broj: 1418/1942., Taj. Broj: 492/1943.; HR-HDA-491-OUP, Broj: 10.847/1942.

28 BARIĆ, Ustroj kopnene vojske domobranstva NDH, 324.

29 Zbornik dokumenata i podataka o NOR-u, tom XIII, knj. 3, dok. br. 55.
} 
Kako su se u međuvremenu nastavljali napadi partizana na prugu Zagreb - Rijeka, iznijet ću primjer u kojem su radnici HDŽ-a bili uspješni u onemogućavanju barem nekih napada. Dvojica čuvara pruge na dionici od Ogulina do Oštarija krajem veljače 1943. u samo nekoliko dana spriječili su dva napada na vlakove. Najprije su na pruzi otkrili minu i o tome uspjeli obavijestiti talijanski oklopni vlak, a zatim su spriječili da vlak HDŽ-a naleti na razrušenu prugu. Talijanska vojska dodijelila im je novčanu nagradu, a zatim je to odlučilo učiniti i Željezničko vijeće HDŽ-a. ${ }^{30}$

Zbog problema u opskrbi hranom stanovništva Gorskoga kotara i Hrvatskoga primorja Zapovjedništvo 2. armije predložilo je sredinom travnja 1943. predstavnicima NDH da ona organizira vlakove koji bi iz Slavonije i istočnih dijelova NDH žurno dopremili hranu za ta područja. Pritom su Talijani zahtijevali da postrojbe NDH preuzmu osiguranje tih vlakova. No vlastima NDH nije bilo lako osigurati hranu za te krajeve, a problem je bilo i osiguranje vlakova koji su ju trebali prevoziti. Krajem svibnja 1943. Glavni stožer domobranstva ocijenio je da bi za osiguranje vlakova na pruzi prema Rijeci bile potrebne velike snage, koje nisu na raspolaganju, pa je predloženo da se hrana za Gorski kotar i Hrvatsko primorje dopremi željeznicom preko Ljubljane do Sušaka, s čime su se Talijani krajem srpnja složili. ${ }^{31}$

Pruga Zagreb - Rijeka u očekivanju talijanske kapitulacije

Krajem srpnja 1943. Benito Mussolini srušen je s vlasti, što je bio uvod u prijelaz Kraljevine Italije na stranu zapadnih Saveznika, koji je objavljen početkom rujna te godine. ${ }^{32}$ Te krupne promjene u taboru sila Osovine odrazile su se i na stanje na pruzi Zagreb - Rijeka.

Prometna uprava njemačke vojske u Beogradu odredila je 1. kolovoza 1943. da se prekine transportni promet s Italijom. To je trebalo provesti i u Karlovcu, gdje su se nalazila dva vlaka s cisternama goriva koja su trebala nastaviti put za Italiju. U Karlovcu nije bilo njemačke vojske koja bi zaustavila te vlakove, nego je u gradu bila talijanska posada. Zato su Nijemci predložili da se vlakovi s cisternama povuku iz Karlovca prema Leskovcu, izvan talijanskoga interesnog područja. O tome je telefonom obaviješten hrvatski kontrolor prometa na željezničkoj postaji u Karlovcu, koji je izjavio da će pokušati postupiti u skladu s njemačkim traženjem. No, to nije bilo moguće provesti, pa su vlakovi s gorivom propušteni za Italiju. Kada je za taj događaj saznalo zapovjedništvo oružanih snaga NDH u Karlovcu, koje nije znalo da je talijanske transporte trebalo zaustaviti po njemačkom nalogu, ono je o svemu obavijestilo Zagreb, upozoravajući da treba čuvati „hladnokrvnost”, odnosno da bi eventualni pokušaj zaustavljanja talijanskih transporta doveo do teških posljedica. Zapravo su Nijemci već

30 HR-HDA-219-MPJR NDH, Glavno ravnateljstvo za promet, Taj. Broj: 1612/1943.

31 HR-HDA-491-OUP, Broj: 6696/1943.

32 BARIĆ, Ustaše na Jadranu, 65-73. 
2. kolovoza povukli odredbu o prekidu prometa s Italijom. ${ }^{33}$

Također je bilo naznaka da je talijanska vojska, u novim okolnostima, spremna na rušenje dijelova pruge Zagreb - Rijeka. Sekcija za uzdržavanje pruga Delnice obavijestila je Zagreb da su Talijani 18. kolovoza 1943. u tunelu Kupjak otvorili minske komore, pa je zatraženo da se onemogući eventualno miniranje toga objekta. ${ }^{34}$

Talijani su 24. kolovoza i na mostu preko rijeke Globornice otvorili minske komore. Postaja Gornje Dubrave o tome je obavijestila pretpostavljene. Na lice mjesta odmah su stigle postrojbe NDH sa dva oklopna vlaka, jednim iz Ogulina i drugim iz Generalskoga Stola. Na pitanje zašto su otvorili komore Talijani su izjavili da su postupali po primljenoj zapovijedi, ali su prekinuli s radom i povukli se u svoj bunker u blizini mosta. Nakon toga ustaše su ponovno zatvorili komore. Prema izvješću Sekcije za uzdržavanje pruga Karlovac, Talijani nisu samo otvorili minske komore na Globorničkom mostu nego su u njih već i postavili eksploziv, ali je on nakon intervencije postrojbi NDH uklonjen, a komore su zatvorene. O tim talijanskim akcijama Glavno ravnateljstvo za promet uputilo je 3. rujna 1943. izvješće njemačkoj Transportnoj komandanturi u Zagrebu. ${ }^{35}$ Nemam podatke da su Talijani nakon objave kapitulacije srušili neke od objekata na pruzi do Rijeke.

\section{Unska pruga}

Godine 1936. francusko poduzeće Batignolles započelo je gradnju pruge između Bihaća i Knina - Unske pruge - čime je sjeverna Dalmacija trebala biti povezana sa zaleđem još jednom linijom osim one kroz Liku. Do proglašenja $\mathrm{NDH}$ Unska pruga nije dovršena. ${ }^{36}$

Hrvatske državne željeznice izvijestile su sredinom listopada 1941. Opće upravno povjereništvo da se jedna talijanska postrojba smjestila u skladišta poduzeća Batignolles u Bihaću. U skladištima se nalazio vrijedan materijal za gradnju Unske pruge, pa su predstavnici vlasti NDH tražili od Talijana neka svoju postrojbu ne smjeste u skladišta da ta sredstva ne bi bila oštećena. Početkom studenoga 1941. Zapovjedništvo 2. armije odbacilo je te žalbe izjavljujući da vlasti u Bihaću i ravnatelj Batignollesa nemaju ništa protiv da se talijanski vojnici smjeste u skladišta toga poduzeća. ${ }^{37}$

U međuvremenu je Ministarstvo prometa NDH pokušavalo nastaviti radove na Unskoj pruzi. Budući da su ustanici uništavali i pljačkali objekte i materijal na trasi pruge, sredinom prosinca 1941. od Zapovjedništva 2. armije za-

\footnotetext{
33 HR-HDA-241-RDŽ, Taj. Broj: 2804/1943.

34 HR-HDA-219-MPJR NDH, Glavno ravnateljstvo za promet, Taj. Broj: 3336/1943.

35 HR-HDA-219-MPJR NDH, Glavno ravnateljstvo za promet, Taj. Broj: 3336/1943., Taj. Broj: 3386/1943.

36 JELINOVIĆ, Borba za jadranske pruge, 139-143.

37 HR-HDA-491-OUP, Broj: 2655/1941.
} 
traženo je da osigura gradilište od Bihaća do Ripača i da se omoguće radovi na nastavku trase prema Kninu. ${ }^{38}$ Sredinom siječnja 1942. Talijani su odgovorili da njihove snage zbog drugih zadataka ne mogu osigurati trasu Unske pruge i nastavak radova na njoj. ${ }^{39}$

Velika župa Bribir i Sidraga u Kninu sredinom veljače 1942. obratila se Ministarstvu prometa NDH, iznoseći da je gradnja Unske pruge već duže obustavljena, odnosno njezino dovršenje odgođeno je na neodređeno vrijeme. Upravo bi Unska pruga bila vrlo korisna za bolju opskrbu sjeverne Dalmacije, posebno tijekom zimskih mjeseci jer je promet željezničkom linijom kroz Liku $\mathrm{u}$ tom razdoblju zbog vremenskih nepogoda prekinut. Zato je ocijenjeno da Unsku prugu treba dovršiti. ${ }^{40}$ Ali te planove nije bilo moguće ostvariti, pa je pruga dovršena tek nakon Drugoga svjetskog rata.

\section{Lička pruga}

Početkom rujna 1941. dužnosnici HDŽ-a iz Gračaca stigli su u Zagreb, gdje su u Ministarstvu prometa podnijeli izvješće. Izjavili su da je pruga od Gračaca do Knina prekinuta za promet 29. srpnja 1941., kada su ustanici na više mjesta prekinuli prugu i brzojavne i telefonske veze duž nje i demolirali željezničke postaje i druge objekte. Željezničari Hrvati s toga dijela pruge pobjegli su u Gračac ili Knin, a željezničari Srbi pridružili su se ustanicima. ${ }^{41}$

Sredinom kolovoza 1941. talijanska vojska ponovno je uspostavila promet na pruzi između Gračaca i Knina, no Talijani na toj liniji nisu jamčili sigurnost predstavnicima HDŽ-a budući da su duž pruge i dalje bili ustanici. U međuvremenu se u Gračacu smjestila brojna talijanska vojska i vojno željezničko osoblje, koji su zauzeli prostorije HDŽ-a i stanove željezničara. Osoblje HDŽa u Gračacu sasvim je podređeno Talijanima, koji su za svoje potrebe počeli koristiti opremu i sredstva hrvatskih željeznica. ${ }^{42}$

Ložionica u Gračacu svakoga je dana za talijansko vojno željezničko osoblje osiguravala šest do devet lokomotiva za održavanje veze od Gračaca do Knina. Problem je bio što talijanski strojovođe nisu poznavali te lokomotive ni značajke pruge po kojoj su vozili, pa je na lokomotivama bilo brojnih oštećenja i kvarova. Dužnosnici HDŽ-a iz Gračaca smatrali su da bi te lokomotive mogle biti i potpuno onesposobljene. ${ }^{43}$

38 HR-HDA-491-OUP, Broj: 4731/1941.

39 HR-HDA-491-OUP, Broj: 373/1942.

40 HR-HDA-491-OUP, Broj: 1720/1942.

${ }^{41}$ HR-HDA-491-OUP, Broj: 183/1941. O stanju na pruzi od Gračaca prema Kninu krajem srpnja i početkom kolovoza 1941. također vidi izvješće predstojnika željezničke postaje u Gračacu Ivana Oreškovića od 12. kolovoza 1941. u: Zbornik dokumenata i podataka o NOR-u, tom V, knj. 32, dok. br. 9.

${ }^{42}$ HR-HDA-491-OUP, Broj: 183/1941.

43 Isto. 
Za razliku od pruge od Gračaca do Knina, predstavnici HDŽ-a iz Gračaca izjavili su da je stanje na pruzi do Gospića uglavnom dobro. Na tom dijelu osoblje je ostalo na svojim mjestima. No, kako je rečeno, Talijani su uspjeli osposobiti i promet do Knina. Među ostalim, srušili su nadvožnjak kraj postaje Malovan koji su ustanici prethodno djelomično minirali da bi promet mogao teći. Tako su teretne kompozicije koje su stizale u Gračac mogle nastaviti put do Knina. No putnički promet bio je obustavljen. Putnici, hrvatski željezničari i domobrani koji su vlakom stizali do Gračaca put do Knina nastavljali su kamionima talijanske vojske. ${ }^{44}$

U vezi s opisanim stanjem državni tajnik Marković ocijenio je 9. rujna 1941. da bi Ministarstvo prometa NDH moralo dobiti jamstva da je željeznička pruga od Gračaca do Knina prohodna i sigurna za radnike HDŽ-a i za prijevoz putnika i robe. To je trebalo osigurati da bi predstavnici HDŽ-a ustanovili stanje na prugama od Knina prema jadranskoj obali, odnosno da bi se prekinula blokada koju „naša Dalmacija kao pasivni kraj” trpi zbog prekida željezničkih veza sa zaleđem. ${ }^{45}$

U istom je razdoblju talijanska željeznička uprava u Ljubljani uputila zahtjev HDŽ-u da na prugu Gračac - Knin uputi materijal za popravak brzojavnih i signalnih uređaja. U vezi s time HDŽ se 10. rujna 1941. obratio Općem upravnom povjereništvu navodeći da nije jasno kome treba uputiti materijal i mogu li radnici HDŽ-a izvesti popravke na toj pruzi. Zato je zatražena obavijest kada će vlakovi HDŽ-a ponovno moći voziti između Gračaca i Knina, a zatim je, u suradnji s Talijanima, trebalo poduzeti potrebno da se stanje na toj pruzi normalizira. ${ }^{46}$

To je riješeno spomenutim sporazumom od 17. rujna 1941., kojim je uređeno pitanje željezničkoga prometa u Razvojačenom pojasu. Tako je dogovoreno da će prugom Gračac - Knin upravljati talijansko osoblje, a kada Zapovjedništvo 2. armije odluči, na toj pruzi trebalo je razmjestiti osoblje HDŽ-a koje je trebalo uspostaviti redovnu službu. ${ }^{47}$ Pretpostavljam da je HDŽ na dionici Gračac - Knin postupno rasporedio svoje osoblje. Ipak, u jednom dopisu Talijanskih državnih željeznica iz svibnja 1942. kaže se da se promet na toj dionici odvija po talijanskim prometnim propisima. ${ }^{48}$

Ubrzo su partizani počeli napadati prugu u Lici. Sekcija za uzdržavanje pruga u Ogulinu izvijestila je u studenom 1941. Inspektorat HDŽ-a u Sušaku da bi s Talijanima trebalo dogovoriti da se promet od postaje Plaški do postaje Studenci odvija samo danju, kada je preglednost pruge bolja. $\mathrm{Na}$ istoj dionici brzinu kretanja vlakova trebalo je ograničiti na $40 \mathrm{~km}$ na sat da bi u slučaju

\footnotetext{
44 Isto.

45 Isto.

46 HR-HDA-491-OUP, Broj: 159/1941.

47 HR-HDA-491-OUP, Broj: 2168/1941.

48 HR-HDA-491-OUP, Broj: 6736/1942.
} 
iskliznuća vlakova na uništenoj pruzi nastale manje štete. Također je na tom dijelu pruge trebalo pojačati talijanske vojničke straže i ophodnje. ${ }^{49}$

Velika župa Gacka i Lika u Gospiću obratila se sredinom prosinca 1941. nadležnim vlastima u vezi s napadima na Ličku prugu, koji su se događali uglavnom noću, pa je stanovništvo počelo izbjegavati putovanje vlakovima koji su prometovali noću. Zato je zatražena promjena voznoga reda, odnosno da se uvede vlak koji bi iz Gračaca kretao u ranim jutarnjim satima da bi u Zagreb stigao u poslijepodnevnim satima istoga dana. ${ }^{50}$

Napadi partizana su se nastavljali. Primjerice, u noći 21./22. travnja 1942. između Plaškoga i Blata razorili su prugu u dužini od 3,4 km, bacajući šinska polja i pragove niz nasip pruge. Također je prerezano oko 100 telefonskih stupova i uništeni su objekti uz prugu. Sekcija za uzdržavanje pruge u Ogulinu procjenjivala je da će za popravak pruge biti potrebno od 10 do 15 dana. Do 30. travnja pruga između Plaškoga i Blata je „provizorno popravljena”, pa su njome mogli prometovati najvažniji vojni i teretni vlakovi, ali brzinom od samo $10 \mathrm{~km}$ na sat. U idućim danima pruga je trebala biti potpuno osposobljena. ${ }^{51}$

Prema podacima njemačke Transportne komandanture u Zagrebu s kraja lipnja 1942., partizani su nastavili s napadima na prugu između Ogulina i Gračaca. ${ }^{52}$ Prema podacima iste komandanture s početka rujna 1942., javni promet na Ličkoj pruzi bio je obustavljen. Nedugo prije u blizini Plaškoga vlak je iskočio iz kolosijeka, pa je promet bio obustavljen dva dana. ${ }^{53}$

Početkom prosinca 1942. u Ogulinu se nalazilo nekoliko desetaka vagona s hranom za stanovništvo i postrojbe NDH u Lici i Hrvatskom primorju. Dio tih vagona upućen je u Liku, ali su ih Talijani, očito zbog nesigurnosti prometa na pruzi, vratili u Ogulin. Zato se iz Zagreba interveniralo pri Općem upravnom povjereništvu kako bi ono utjecalo na Talijane da ti vagoni dobiju prvenstvo pri otpremi na odredište. Pritom se upozoravalo na činjenicu da se hrana (bundeve, krumpir, kupus) uglavnom nalazi u otvorenim vagonima, zbog čega joj prijeti propadanje. ${ }^{54}$

Inače, krajem rujna 1942. u jednom dokumentu Općega upravnog povjereništva NDH u vezi s držanjem talijanskih postrojbi u Lici ocijenjeno je da je njihova slabost u tome što

„[...] obraćaju pažnju samo na željezničku prugu, premda se osiguranje te pruge neće izvršiti samim njezinim čuvanjem, već uništenjem partizana u bližim i daljim položajima oko pruge". ${ }^{55}$

49 HR-HDA-491-OUP, Broj: 3753/1941.

${ }^{50}$ HR-HDA-491-OUP, Broj: 4833/1941.

${ }^{51}$ HR-HDA-491-OUP, Broj: 4237/1942.

52 Zbornik dokumenata i podataka o NOR-u, tom XII, knj. 2, dok. br. 94.

53 Zbornik dokumenata i podataka o NOR-u, tom XII, knj. 2, dok. br. 144.

${ }^{54}$ HR-HDA-491-OUP, Broj: 13.640/1942.

55 HR-HDA-250-UV, Zapovjedničtvo Ustaške vojnice, Nadzorni odjel, Taj. Broj: 198/1942. 
No, ta nadanja predstavnika NDH neće se ostvariti. Upravo suprotno, talijanska vojska počela se u ožujku 1943. povlačiti iz Like prema Hrvatskom primorju i Gorskom kotaru odnosno prema Dalmaciji. ${ }^{56}$ Krajem toga mjeseca u Zagrebu su primljeni podaci da se Talijani povlače s pruge u smjeru Ogulina odnosno Pađena kraj Knina. ${ }^{57}$

Zanimljivo je izvješće o tome koje je Ravnateljstvu državnih željeznica u Zagrebu podnio nadstojnik željezničke postaje u Javorniku. On je iznio da su u drugoj polovini ožujka 1943. talijanski vojnici počeli govoriti da „skoro napuštaju” Ličku prugu. U Javornik je 30. ožujka stigao talijanski željeznički transport iz Vrhovina. Talijanski časnici iz toga transporta izjavili su da će se postupno povlačiti prema Ogulinu, nakon čega će pruga ostati bez osiguranja i time će biti zatvorena za promet. Nadstojnik postaje u Javorniku ipak je 3. travnja primio brzojav državnoga tajnika za promet Markovića u kojem je stajalo da će talijanske snage koje se povlače s odsjeka pruge Ogulin - Vrhovine zamijeniti postrojbe NDH. No Talijani su nadstojniku tvrdili da mora napustiti postaju jer će talijanske zalaznice u povlačenju spaljivati objekte, a sve osobe na koje naiđu smatrat će partizanima. Budući da postrojbe NDH nisu stigle u Javornik, 5. travnja nadstojnik postaje evakuirao je postaju i svoje ljude i njihove obitelji u Ogulin. U svemu tome nije bilo moguće provesti organiziranu evakuaciju dok je talijanska vojska u povlačenju demolirala državnu imovinu NDH. Ministarstvo prometa NDH krajem travnja 1943. obratilo se Općem upravnom povjereništvu, navodeći da je postaja Javornik napuštena „bez sistema i reda”, a po svemu sudeći na isti su način napuštene i ostale postaje na Ličkoj pruzi. Zato je zatraženo da se intervenira kod Talijana da bi se ubuduće spriječili slučajevi u kojima NDH trpi štetu zbog jednostranih talijanskih postupaka. ${ }^{58}$

Ubrzo nakon talijanskoga povlačenja partizani su ovladali Likom te opkolili i Gospić, ali se posada NDH u njemu uspjela održati. ${ }^{59}$ Takvim razvojem događaja Lička pruga bila je potpuno prekinuta za promet.

\section{Napuštanje Gračaca}

S izgradnjom i konačnim dovršenjem Ličke pruge 1925. u Gračacu je podignuta željeznička ložionica s radionicama. ${ }^{60}$ Opisao sam kako je talijanska vojska u ljeto 1941. upotrijebila željezničku infrastrukturu u Gračacu za uspostavu prometa do Knina. No kako su od sredine 1942. Talijani povlačili svoje snage iz NDH, počeli su razmatrati i povlačenje iz Gračaca. ${ }^{61}$

\footnotetext{
${ }^{56}$ ORLOVIĆ, Šesta lička proleterska divizija, 142.

57 HR-HDA-219-MPJR NDH, Glavno ravnateljstvo za promet, Taj. Broj: 1220/1943., Taj. Broj: 1256/1943.

${ }^{58}$ HR-HDA-491-OUP, Broj: 4171/1943.

59 ORLOVIĆ, Šesta lička proleterska divizija, 142-204.

60 POPOVIĆ, BJELOBABA, „Općina Gračac u razdoblju od 1918. do aprila 1942. godine”, 324-325.

${ }^{61}$ Zbornik dokumenata i podataka o NOR-u, tom XIII, knj. 2, dok. br. 81.
} 
Radnici HDŽ-a u Gračacu primijetili su krajem studenoga 1942. da se talijanska posada u tom mjestu počela evakuirati. Ubrzo su Talijani izjavili predstavnicima NDH da će napustiti Gračac i iz njega evakuirati službenike NDH i njihove obitelji. No, do konačnoga napuštanja mjesta od radnika HDŽa zahtijevalo se da ostanu na svojim dužnostima. Zatim su Talijani početkom prosinca 1942. objavili da će vlast u Gračacu predati četnicima. To je među radnicima HDŽ-a izazvalo zabrinutost i mnogi od njih više se nisu pojavili na radnim mjestima, a talijansko zapovjedništvo zaprijetilo je strijeljanjem željezničarima koji nisu na svojem radnome mjestu. U takvoj situaciji predstavnici HDŽ-a u Gračacu zahtijevali su od pretpostavljenih da u Gračac budu upućene postrojbe NDH, kao i upute kako postupiti u postojećim okolnostima. U Zagrebu je 2. siječnja 1943. odlučeno da osoblje HDŽ-a u Gračacu „nadalje ima ostati na svojim mjestima". ${ }^{2}$

Zapravo se talijanska vojska nakon napuštanja samoga mjesta ipak zadržala na željezničkoj postaji u Gračacu. ${ }^{63}$ Krajem siječnja 1943. predstavnik vlasti $\mathrm{NDH}$ iz Knina posjetio je Gračac da ispita stanje državnih ustanova u tom mjestu. U vezi s time Ministarstvo prometa NDH odredilo je da se, čim prilike budu dopuštale, u Gračac uputi povjereništvo HDŽ-a koje će napraviti inventuru željezničke imovine ${ }^{64}$ No, to nije bilo moguće provesti. Talijanska se vojska 4. ožujka 1943. konačno i u cijelosti povukla iz Gračaca, a iz mjesta su se povukli i četnici. Već idućega dana u Gračac su ušli partizani. ${ }^{65}$

Inspektorat HDŽ-a u Sušaku izvijestio je 10. ožujka 1943. Zagreb o povlačenju Talijana iz Gračaca, odnosno da su se njihove snage povukle do postaje Pađene. Radnici HDŽ-a s obiteljima su se povukli u Lovinac, a dio u Drniš i Knin, gdje su nastavili sa službom. ${ }^{66}$

Vlasti NDH primile su različite podatke o tome da je talijanska vojska prilikom napuštanja Gračaca iz njega evakuirala znatna sredstva koja su bila vlasništvo HDŽ-a, od lokomotiva do raznih vrijednih strojeva iz željezničke ložionice u Gračacu, i da je ta imovina upućena na teritorij anektirane Dalmacije, odnosno u Split i Šibenik. Također je bilo slučajeva da su talijanski vojnici u Drnišu i Kninu pokušavali prodati dijelove imovine HDŽ-a koja je odnesena iz Gračaca. Vlasti u Zagrebu zatražile su Opće upravno povjereništvo da od Zapovjedništva 2. armije dobije informacije što se dogodilo s lokomotivama i drugom željezničkom imovinom evakuiranom iz Gračaca. Dopisom od 20. svibnja 1943. Zapovjedništvo 2. armije opširno je izvijestilo koja su sredstva evakuirana iz Gračaca i kamo su zatim upućena. Rečeno je da su gotovo svi vagoni HDŽ-a iz Gračaca prebačeni na područje pod nadzorom talijanske voj-

${ }^{62}$ HR-HDA-219-MPJR NDH, Glavno ravnateljstvo za promet, Taj. Broj: 1752/1942.

63 ORLOVIĆ, Šesta lička proleterska divizija, 53.

${ }^{64}$ HR-HDA-219-MPJR NDH, Glavno ravnateljstvo za promet, Taj. Broj: 554/1943.

65 ORLOVIĆ, Šesta lička proleterska divizija, 142.

66 HR-HDA-219-MPJR NDH, Glavno ravnateljstvo za promet, Taj. Broj: 1012/1943. 
ske, kao i sve lokomotive koje se moglo izvući. Cjelokupna zaliha ugljena koja je bila u Gračacu dopremljena je u Knin. Talijani su evakuirali i drugu opremu, primjerice željezničku centrifugalnu ralicu za snijeg, kao i razne pričuvne dijelove. Kada je riječ o strojevima radionica u Gračacu, oni su uglavnom onesposobljeni, a tek manjim dijelom evakuirani. Određena sredstva nisu mogla biti evakuirana zbog nedostatka vremena i radne snage. Pismohranu HDŽ-a u Gračacu hrvatski su službenici evakuirali još u siječnju 1943. godine. Talijani su rekli da je dio sredstava evakuiranih iz Gračaca već predan predstavnicima HDŽ-a u Kninu, a dio je dopremljen do Splita, zatim brodovima do Rijeke i konačno predan na korištenje HDŽ-u u Hrvatskim Moravicama. ${ }^{67}$

Početkom 1943., prije nego što su Talijani potpuno napustili prugu u Lici i Gračac, Ravnateljstvo HDŽ-a u Zagrebu tražilo je da se u Ogulin vrati nekoliko lokomotiva koje su se nalazile u Gračacu. ${ }^{68}$ Razumljivo, nakon talijanskoga povlačenja s Ličke pruge i iz Gračaca postalo je nemoguće te lokomotive prugom vratiti u Ogulin. Nakon toga Glavno ravnateljstvo za promet Ministarstva prometa i Ravnateljstvo HDŽ-a u Zagrebu nastavili su prikupljati podatke o lokomotivama koje su bile onesposobljene i zatim napuštene na Ličkoj pruzi, o lokomotivama koje nisu evakuirane iz Gračaca, kao i o lokomotivama koje su se trenutačno nalazile u Kninu i Splitu. Što se tiče lokomotiva HDŽ-a na dalmatinskim prugama koje su koristili Talijani, trebalo je zatražiti da neke od njih budu vraćene, a neke su Talijani mogli nastaviti koristiti, ali je za njih trebalo tražiti naplatu najamnine. ${ }^{69}$

\section{Dalmatinske pruge}

Rimskim ugovorima od 18. svibnja 1941. određena je granica između NDH i Kraljevine Italije, čime je obalni dio Dalmacije od Zadra do Splita pripao Italiji. Unatoč talijanskoj aneksiji Splita, u njemu su nastavile djelovati ustanove i osoblje HDŽ-a. Teško je reći zašto Talijani nisu odmah u cijelosti preuzeli upravu i vođenje željeznice u Splitu. U jednom dopisu Ministarstva prometa NDH iz veljače 1942. stoji da Talijanske državne željeznice nisu preuzele upravu u Splitu jer je to područje nepovezano s njihovim prugama. ${ }^{70}$

Pretpostavljam da se razlog ostanka HDŽ-a u Splitu temeljio na praktičnim razlozima: talijanski anektirani teritorij na prostoru Splita bio je "plitak" i na njemu do granice s NDH nije bilo praktično uspostavljati talijansku željezničku upravu.

U vezi s organizacijom željezničkoga prometa na pruzi Split - Split predgrađe - Solin predstavnici Talijanskih državnih željeznica i talijanske vojske

67 HR-HDA-491-OUP, Broj: 4556/1943.

68 HR-HDA-219-MPJR NDH, Glavno ravnateljstvo za promet, Taj. Broj: 822/1943.

69 HR-HDA-219-MPJR NDH, Glavno ravnateljstvo za promet, Taj. Broj: 1239/1943., Taj. Broj: 1240/1943., Taj. Broj: 1554/1943.

70 HR-HDA-491-OUP, Broj: 1478/1942. 
izjavili su u listopadu 1941. da se ta pruga nalazi pod upravom Ravnateljstva HDŽ-a Zagreb. Budući da je u međuvremenu u Sušaku uspostavljeno talijansko Izaslanstvo za vojne transporte i njemu podređeni Inspektorat HDZ̆-a, određeno je, kao privremeno rješenje, da hrvatsko željezničko osoblje na splitskom području bude podređeno Inspektoratu. ${ }^{71}$

Tijekom travnja 1942. talijanske vlasti u Splitu uhitile su neke željezničare HDŽ-a koji su bili povezani s komunistima. Zato je Giuseppe Bastianini, talijanski guverner Dalmacije, zahtijevao od Rima da se u Split razmjesti talijansko željezničko osoblje. ${ }^{72}$

U skladu s time, predstavnik Talijanskih državnih željeznica u Sušaku obavijestio je sredinom svibnja 1942. Inspektorat HDŽ-a da po odredbi guvernera Dalmacije osoblje HDŽ-a u Splitu u idućih mjesec dana mora biti zamijenjeno talijanskim željezničarima. Zato je od Inspektorata zatraženo da započne s premještanjem osoblja HDŽ-a iz Splita. Cjelokupna oprema na postajama Split, Split-predgrađe i Solin trebala je biti predana Talijanskim državnim željeznicama. Talijani su predvidjeli da željeznička postaja Perković-Slivno bude osposobljena kao točka na kojoj će ubuduće HDŽ i Talijanske državne željeznice izmjenjivati lokomotive i osoblje. U međuvremenu su talijanski željezničari trebali upravljati prometom sve do Knina, a na postaje do Knina trebalo je uputiti i talijanske nadstojnike postaja. Po primitku toga dopisa Inspektorat HDŽ-a u Sušaku odgovorio je da ne može pregovarati o tim pitanjima bez uputa pretpostavljenih vlasti. Ministarstvo vanjskih poslova NDH priopćilo je Poslanstvu Kraljevine Italije u Zagrebu da odluka guvernera Dalmacije o odstranjenju radnika HDŽ-a nije dogovorena s Ministarstvom prometa NDH. Riječ je o više stotina osoba čiji se domovi nalaze u Splitu i koje će biti pogođene odlukom o napuštanju Splita. Također je upozoreno da se postaje Perković-Slivno i Solin prema Rimskim ugovorima nalaze na teritoriju NDH. Ocijenjeno je da sve navedeno, kao i talijanska namjera da njezini željezničari imaju nadležnosti na teritoriju NDH, ide na njezinu štetu, a predložene promjene nisu korisne u okolnostima kada se željeznički promet odvija s brojnim poteškoćama. Zato je od Poslanstva Kraljevine Italije zatraženo da poradi na opozivu odluke guvernera Dalmacije o uklanjanju radnika HDŽ-a iz Splita i da se pitanja povezana s tim problemom riješe sporazumom središnjih vlasti NDH i Italije. ${ }^{73}$

No Talijani su 12. lipnja 1942. uhitili hrvatsko vlakopratno osoblje na vlakovima koji su toga dana stigli u Split, a uhićen je i dio osoblja HDŽ-a koje je radilo u postaji i ložionici Split, odnosno u gradu je uhićen svatko tko je nosio odoru HDŽ-a. Talijani su zahtijevali da postaja i ložionica u Splitu budu predane njihovu osoblju. Ali kako nije bilo dovoljno talijanskih željezničara da preuzmu cjelokupnu službu, Talijani su izjavili da će postupno svojim ljudima

\footnotetext{
${ }^{71}$ HR-HDA-491-OUP, Broj: 2168/1941.

72 Narodnooslobodilačka borba u Dalmaciji 1941-1945. Zbornik dokumenata, knj. 2, dok. br. 286.

73 HR-HDA-491-OUP, Broj: 6736/1942.
} 
zamijeniti hrvatsko osoblje. Talijanski kontrolor prometa upozorio je radnike HDŽ-a da postoji mogućnost da će biti uhićeni ako budu nosili hrvatske odore i znakovlje, pa su oni službu nastavili obavljati u civilnoj odjeći. Osim toga Talijani su prekinuli željeznički promet od Splita do Knina, Sinja i do postaja Perković-Slivno i Dabar. Ni vlakovi koji su stizali iz Zagreba nisu mogli voziti do Splita, nego samo do Knina. ${ }^{74}$

Predstavnici HDŽ-a u Splitu i druge vlasti NDH u Dalmaciji o tim su događajima obavijestili Zagreb. Ocijenjeno je da je sve povezano s talijanskom namjerom da postaja Perković-Slivno bude ona na kojoj će se izmjenjivati hrvatsko i talijansko željezničko osoblje, odnosno lokomotive HDŽ-a i Talijanskih državnih željeznica. Kako ta postaja nije bila opremljena za takve poslove, ostajao je dojam da Talijani namjeravaju postaju Knin privremeno pretvoriti u pograničnu postaju, odnosno da se u njoj izmjenjuju osoblje i lokomotive. ${ }^{75}$

U međuvremenu je guverner Bastianini 13. lipnja 1942. izvijestio vlasti u Rimu da je NDH imala 14 mjeseci da premjesti svoje željezničare iz Splita. Ti su željezničari, ocijenio je Bastianini, protutalijanski raspoloženi, ali je smatrao da su i protivnici NDH. Radi očuvanja sigurnosti jedino je rješenje da talijanske vlasti te željezničare uhite ili da ih Ministarstvo prometa NDH napokon premjesti na radna mjesta na svojem teritoriju. U Splitu bi u željezničkoj službi mogli ostati samo oni radnici HDŽ-a koji imaju uvjete postati talijanski državljani. Bastianini je upozorio da se u Splitu već nalazi 100 radnika Talijanskih državnih željeznica, pa je „uvredljivo” za talijansku vlast da oni moraju čekati preuzimanje posla od hrvatskih željezničara. ${ }^{76}$

Nadstojnik Inspektorata HDŽ-a u Sušaku ing. Novak 15. lipnja 1942. zatražio je od vlasti u Zagrebu da poduzmu korake da bi se prekinula talijanska „samovolja” kojom su zatvorene željezničke linije od Splita prema zaleđu jer je time stanovništvo NDH stavljeno u nepovoljan položaj. Također je izvijestio da je početkom lipnja posjetio Split da bi razgovarao s nadstojnicima tamošnjih jedinica HDŽ-a. Cilj razgovora bio je razmotriti okolnosti koje će nastati kada Talijani započnu uklanjanje osoblja HDŽ-a iz Splita. Novak je objasnio da hrvatski željezničari koji žive u Splitu namjeravaju u njemu i ostati, a neki će zatražiti i prelazak u službu Talijanskih državnih željeznica. Ocijenio je da u talijansku službu neće prijeći zbog „uvjerenja ili osjećaja”, nego zato što su na to prisiljeni okolnostima. Zapravo bi za NDH bilo „donekle povoljno” da što više „naših ljudi” ostane u Splitu za „svaku eventualnost”.77

Ministarstvo prometa NDH brzojavom od 22. lipnja 1942. obavijestilo je osoblje HDŽ-a u Splitu da im je prepušteno na volju hoće li ostati u Splitu i prijeći u službu Talijanskih državnih željeznica ili će ostati u službi HDŽ-a i u tom slučaju biti premješteni na službu izvan Splita, odnosno na teritorij NDH.

\footnotetext{
74 Isto.

75 Isto

76 Narodnooslobodilačka borba u Dalmaciji 1941-1945. Zbornik dokumenata, knj. 2, dok. br. 352.

77 HR-HDA-491-OUP, Broj: 6736/1942.
} 
U međuvremenu je Ministarstvo prometa interveniralo i kod Ministarstva vanjskih poslova NDH i kod Općega upravnog povjereništva da bi ponovno bio uspostavljen promet od Splita do Knina, Sinja, Perkovića-Slivna i Dabra. Ministarstvo prometa upozorilo je da talijanske vlasti u anektiranoj Dalmaciji nisu nadležne bez dogovora s vlastima NDH prekinuti promet sa zaleđem. ${ }^{78}$

S talijanskom odlukom o preuzimanju uprave željeznica u Splitu otvaralo se pitanje novoga uređenja prometa na prugama od Splita do Knina i Sinja. Ministarstvo prometa NDH smatralo je da bi to trebalo urediti na konferenciji nadležnih hrvatskih i talijanskih željezničkih stručnjaka. ${ }^{79}$ Pritom je ing. Novak tijekom lipnja i srpnja savjetovao Zagreb da bi bilo dobro da se osoblje HDŽ-a nakon napuštanja Splita zadrži na postaji Solin, odnosno da ta postaja služi kao pogranična, na kojoj će se izmjenjivati lokomotive i osoblje, a ne postaja Perković-Slivno kako su to zamišljali Talijani. ${ }^{80}$

Na kraju je ing. Novak 19. kolovoza 1942., kada je posjetio Split, s talijanskim predstavnicima postigao sporazum o tome da Talijanske državne željeznice preuzmu željeznički promet na splitskom području. Dogovoreno je da će one potpuno preuzeti službu u postajama Split, Split-predgrađe i Solin. Na postajama od Kaštel Staroga do Knina trebalo je rasporediti, kao izaslanike, talijanske nadstojnike postaja, a HDŽ je kao izaslanike trebao imati svoje predstojnike postaja u Splitu, Splitu-predgrađe i Solinu. Također je dogovoreno da će do 15. rujna 60 hrvatskih željezničara u Splitu biti stavljeno na raspolaganje upravi HDŽ-a, a preostali do 15. listopada, a paralelno s tim njihove poslove trebali su preuzeti talijanski željezničari. U sporazumu je stajalo da su njegove odredbe privremene i podložne promjenama u skladu s budućim dogovorima. ${ }^{81}$

$\mathrm{U}$ vezi s tim sporazumom ing. Novak obratio se državnom tajniku Markoviću. Objasnio je da je tražio sazivanje hrvatsko-talijanske konferencije na kojoj bi se riješilo pitanje željezničkoga prometa na području Splita. To je trebalo bilo povezano s konačnim i točnim određivanjem granične crte između $\mathrm{NDH}$ i Italije na tom području, koja i dalje nije bila uređena. Kako ta pitanja nisu bila riješena, stanje je bilo nesređeno, a željeznički promet neracionalno organiziran. Osim toga osoblje HDŽ-a u Splitu bilo je u neprestanoj opasnosti da će ih talijanske vlasti uhititi kao subverzivne elemente. Da bi se stanje uredilo i riješili barem neki od problema, Novak je odlučio sklopiti sporazum s talijanskim predstavnicima. Novak je u dopisu Markoviću naglasio da taj sporazum nije konačan, da se njegove odredbe mogu mijenjati, pa nakon konačnoga određivanja granične crte između talijanske Dalmacije i NDH može biti organizirana međudržavna talijansko-hrvatska konferencija koja bi ustanovila

\footnotetext{
78 Isto.

79 HR-HDA-219-MPJR NDH, Glavno ravnateljstvo za promet, Taj. Broj: 410/1942.

80 HR-HDA-219-MPJR NDH, Glavno ravnateljstvo za promet, Taj. Broj: 384/1942.; HRHDA-491-OUP, Broj: 6736/1942.

${ }^{81}$ HR-HDA-219-MPJR NDH, Glavno ravnateljstvo za promet, Taj. Broj: 696/1942.
} 
odvijanje željezničkoga prometa na splitskom području. Premda je Novak prije smatrao da bi HDŽ trebao zadržati željezničku postaju Solin, u svojem dopisu Markoviću ipak je morao spomenuti da je ta postaja prepuštena Talijanima jer je to bilo „nužno”, odnosno zato što na njoj ionako već službuju talijanski vojni željezničari. ${ }^{82}$

Državni tajnik Marković obavijestio je početkom rujna 1942. Inspektorat HDŽ-a u Sušaku da se taj sporazum ne prihvaća, da u njegovu donošenju nisu sudjelovali nadležni predstavnici HDŽ-a, a očito je da ni talijanski predstavnici nisu imali ovlaštenje pretpostavljenih za sklapanje sporazuma. Zato je od Inspektorata zatraženo da poduzme potrebno da se odredbe toga sporazuma ne primijene. Marković je o svojem stajalištu obavijestio i Glavno ravnateljstvo Državnih željeznica u Rimu, upozoravajući da bi uređenje prometa na području Splita trebalo biti riješeno na konferenciji ovlaštenih predstavnika Italije i $\mathrm{NDH}$, što je Zagreb već tražio, ali nije primljen odgovor iz Rima. ${ }^{83}$

Marković je očito smatrao da je Novak u popuštanju Talijanima prekoračio svoja ovlaštenja. Zato je Novak ispitan da bi objasnio zašto je potpisao privremeni sporazum s Talijanima. Novak je izjavio da je postupio u dobroj namjeri, kao i da su mu talijanski predstavnici tvrdili da treba naći neko rješenje da željeznički promet na splitskom području ne bi bio potpuno prekinut. ${ }^{84}$

Kada je talijansko Izaslanstvo za vojne transporte u Sušaku obaviješteno da HDŽ neće prihvatiti privremeni sporazum o uređenju prometa na području Splita, ocijenilo je da je to novi dokaz nespremnosti HDŽ-a za suradnju. Izaslanstvo je zato odredilo da se sporazum mora poštovati, a predstavnici NDH upozoreni su da je 15. listopada 1942. posljednji rok do kojega osoblje HDŽ-a mora napustiti Split. ${ }^{85}$

U međuvremenu je Poslanstvo NDH u Rimu tijekom rujna 1942. primilo i odgovor talijanskoga Ministarstva vanjskih poslova zašto su u lipnju te godine u Splitu uhićeni radnici HDŽ-a. U odgovoru je stajalo da su neki od tih željezničara bili suradnici komunista. Ipak su pušteni na slobodu jer su bili službenici „prijateljske države”. Također je rečeno da je željeznički promet iz Splita prema zaleđu u lipnju te godine bio prekinut upravo da bi se onemogućilo da komunisti iz Splita putuju prema unutrašnjosti. ${ }^{86}$

Naposljetku je od 12. do 17. listopada 1942. u Rimu održana konferencija o uređenju pograničnoga željezničkog prometa između NDH i anektiranoga dijela Dalmacije, odnosno između NDH i Crne Gore. Konferencija nije uspjela. Što se tiče prometa prema Crnoj Gori, Talijani o tome nisu željeli raspravljati. Kada je riječ o prometu između anektirane Dalmacije i NDH, Talijani su

\footnotetext{
82 Isto.

83 Isto.

84 Isto.

85 HR-HDA-219-MPJR NDH, Glavno ravnateljstvo za promet, Taj. Broj: 1694/1942.

86 Isto.
} 
inzistirali da njihove državne željeznice obavljaju cjelokupnu službu od Splita do Knina i Sinja jer to zahtijevaju potrebe talijanske vojske na tom području, a svoj su zahtjev temeljili na sporazumu koji je s Talijanima u Splitu potpisao ing. Novak. ${ }^{87}$

Državni tajnik Marković obratio se 23. listopada 1942. Ministarstvu vanjskih poslova NDH. U dopisu je iznio niz pritužbi na talijansku vojsku, koja svojim jednostranim postupcima otežava željeznički promet, a zatim da su Talijani „silom” preuzeli obavljanje prometne službe na prugama od Splita do Knina i Sinja, sa svojim strojovođama, vlakovođama, kondukterima i kočničarima, a na spomenutim prugama postavili su i svoje nadstojnike postaja. Nakon toga sklopljen je i „nekakav privremeni sporazum”, koji Marković nije htio priznati, a u listopadu 1942. u Rimu je održana i spomenuta konferencija na kojoj Talijani nisu željeli pristati na traženja HDŽ-a. Zato je Marković od Ministarstva vanjskih poslova NDH tražio da poduzme potrebno da bi se održala nova konferencija, na kojoj bi se našlo rješenje na temelju „naših nacrta”, i da se osnuje mješovito hrvatsko-talijansko povjerenstvo koje bi se bavilo rješavanjem postojećih nesuglasica. ${ }^{88}$

Talijani su dakle jednostrano, paralelno s protjerivanjem osoblja HDŽ-a iz Splita, preuzeli i upravu nad prugama u dijelu Dalmacije koji je bio u sastavu NDH. Do sredine 1943. stanje se očito nije promijenilo u skladu s traženjima državnoga tajnika Markovića. I u tom su razdoblju talijanske vlasti uhićivale službenike HDŽ-a koji su dolazili u Split kako bi posjetili svoje obitelji koje nisu mogle naći smještaj na teritoriju NDH. Štoviše, Talijani su radili na tome da se onemogući kretanje službenika HDŽ-a i na hrvatskom dijelu pogranične pruge (Perković-Slivno - Solin i Solin - Klis). Kada je ing. Novak sredinom srpnja 1943. o tome pisao državnom tajniku Markoviću, ocijenio je da je očita težnja Talijana da onemoguće dolazak radnika HDŽ-a u Split budući da bi oni u slučaju eventualnoga „nepovoljnog momenta” za Talijane za njih mogli biti "nezgodni". 89

Novak je izvijestio Markovića da je HDŽ do ljeta 1943. ipak imao dva teretna vlaka na pruzi Perković-Slivno - Knin, ali su Talijani zatim preuzeli i te vlakove. Isto tako Talijani su zadržali lokomotive HDŽ-a evakuirane iz Gračaca - uostalom bez tih lokomotiva oni i ne bi mogli prometovati na dalmatinskim prugama. Nakon svih tih događaja postavljalo se pitanje kako upotrijebiti osoblje HDŽ-a na postajama u Dalmaciji (Drniš, Knin, Perković-Slivno, Sinj, Solin). Da bi oni mogli biti iskorišteni i da bi HDŽ mogao uspostaviti promet u svojem dijelu Dalmacije trebalo je, nakon gubitka infrastrukture u Splitu, uspostaviti odnosno proširiti ložionice i radionice u Kninu i Sinju. Za sekciju za uzdržavanje pruga koja je morala napustiti Split trebalo je riješiti pitanje

\footnotetext{
87 Isto.

${ }_{88}$ HR-HDA-219-MPJR NDH, Glavno ravnateljstvo za promet, Taj. Broj: 618/1943.

89 HR-HDA-491-OUP, Broj: 6179/1943.
} 
smještaja u Solinu. No, za sve to trebalo je financijskih sredstava, odnosno osigurati opremu i podići instalacije. ${ }^{90}$

U međuvremenu je HDŽ zadržao upravu samo nad industrijskom prugom Drniš - Velušić, kojom se iz rudnika na tom području prevozio boksit za njemačke potrebe. Lokomotive na toj pruzi bile su u lošem stanju, nisu popravljane tri godine, ali je Novak ocijenio da Talijani prijevoz boksita prepuštaju HDŽ-u da - u slučaju eventualnih problema - ne bi za to trebali snositi nikakvu odgovornost. ${ }^{91}$

U vezi s opisanim stanjem Novak je Markoviću predložio dva rješenja. Prvo bi bilo da se osiguraju potrebna financijska i materijalna sredstva za uspostavu ložionice i radionica u Kninu i Sinju. Nakon toga osoblje HDŽ-a moglo bi preuzeti službu na prugama u dijelu Dalmacije koji je bio u sastavu NDH. Također bi preko Ministarstva vanjskih poslova NDH trebalo intervenirati da Talijani dopuste da obitelji službenika HDŽ-a koje i dalje žive u Splitu mogu ondje ostati do kraja rata jer je vrlo teško naći stan u NDH. Trebalo je omogućiti službenicima HDŽ-a koji su morali napustiti Split da posjećuju svoje obitelji koje ondje žive. Isto je tako od nadležnih talijanskih vojnih i željezničkih vlasti trebalo tražiti da isprazne stanove HDŽ-a koje su zauzeli na različitim postajama. Kada bi Talijani to učinili, u te bi se stanove moglo smjestiti obitelji nekih hrvatskih željezničara koje su i dalje živjele u Splitu. Ako sve to nije moguće, Novak je Markoviću predložio drugo rješenje, odnosno da se tijekom ljeta 1943. cjelokupno osoblje HDŽ-a koje nije potrebno u Dalmaciji preseli, zajedno s obiteljima i imovinom, u unutrašnjost NDH i da im se ondje osigura smještaj..$^{92}$

Kao što je prikazano, u posljednjim mjesecima prije kapitulacije Talijani su jednostrano u cijelosti preuzeli vođenje prometa na željezničkim prugama u dijelu Dalmacije koji je pripadao NDH. Zato je prisutnost znatnoga dijela osoblja HDŽ-a na tom području postala suvišna, posebno bez infrastrukture koju su Talijani preuzeli u Splitu, a koja nije postojala u Kninu i Sinju. No, pretpostavljam, nijedno od rješenja koje je Novak u srpnju 1943. predložio Markoviću nije moglo biti provedeno do početka rujna te godine, kada je proglašena talijanska kapitulacija.

\section{Bosanske pruge}

Kada je 17. rujna 1941. u Zagrebu sklopljen hrvatsko-talijanski sporazum o organizaciji željezničkoga prometa u dijelu NDH u kojem je talijanska vojska preuzela upravu, također je određeno da će Izaslanstvo za vojne transporte u Sušaku uputiti Ravnateljstvu HDŽ-a u Sarajevu potrebno osoblje koje će urediti pitanje prometa na uskotračnim prugama od Dubrovnika do Metkovića

\footnotetext{
90 Isto.

91 Isto.

92 Isto.
} 
i Sarajeva, odnosno od Dubrovnika do Bileće i Nikšića i od Dubrovnika do Grude. Tako je i promet na tim prugama trebao biti uređen kao na drugim prugama na područjima na kojima je talijanska vojska preuzela upravu. ${ }^{93}$

I na uskotračnoj pruzi od Sarajeva prema Hercegovini odnosno Dubrovniku ubrzo se pojavio problem partizanskih napada. Željeznička postaja Sarajevo izvijestila je krajem prosinca 1941. pretpostavljene da bi trebalo bolje vojnički osigurati pruge u južnoj Hercegovini. Osiguranje je traženo i od talijanske vojske, ali ona nije poduzela potrebne mjere. Promet je bio ugrožen na području Bradine i Trebinja. Zbog tih problema u pitanje je dovedena opskrba Dubrovnika hranom, a nije se mogao transportirati ni boksit za njemačke potrebe. ${ }^{94}$

Njemačka Transportna komandantura u Zagrebu izjavila je krajem svibnja 1942. da se promet na pruzi Mostar - Dubrovnik trenutačno odvija, ali se pretpostavljalo da su mogući novi napadi partizana i novi prekidi na toj pruzi. Talijanska je vojska zbog sigurnosti odredila da se željeznički promet Mostar Dubrovnik ne odvija tijekom kasnijih poslijepodnevnih sati i noću. ${ }^{95}$

Mjesec dana poslije Transportna komandantura u Zagrebu nije raspolagala podacima o napadima na željezničku prugu Mostar - Dubrovnik. ${ }^{96}$ Početkom rujna 1942., prema istom izvoru, promet na toj pruzi i dalje se odvijao normalno, štoviše povećan je prijevoz boksita za njemačke potrebe. ${ }^{97}$

I dok je, iz njemačke perspektive, stanje na pruzi od Mostara do Dubrovnika, a očito i od Mostara do Sarajeva, bilo relativno povoljno, odnosi između Ravnateljstva HDZ̆-a u Sarajevu i talijanske vojske tijekom 1942. nisu bili dobri. Početkom te godine spomenuto ravnateljstvo žalilo se Ministarstvu prometa NDH da talijanska vojska neracionalno upotrebljava vozni park. Predstavnici HDŽ-a uložili su sve napore da udovolje potrebama talijanske vojske, ali hrvatski željezničari nisu nailazili na susretljivost i povjerenje Talijana. Ravnateljstvo HDŽ-a u Sarajevu iznijelo je niz primjera talijanske samovolje i kršenja propisa HDŽ-a. Kada bi se talijanska vojska prestala miješati u prometovanje i to prepustila HDŽ-u, zaključeno je, promet bi mnogo bolje funkcionirao, što bi bilo u interesu i samih Talijana. Od Ministarstva prometa u Zagrebu zatraženo je da zbog svega rečenog intervenira kod Talijana, što bi dovelo do poboljšanja prometa, a time bi bio olakšan i prijevoz hrane za opskrbu pasivnih krajeva. ${ }^{98}$

No Talijani su imali suprotno mišljenje. Kraljevska talijanska vojna misija u Zagrebu žalila se tijekom lipnja 1942. Ministarstvu prometa NDH da Ravnateljstvo HDŽ-a u Sarajevu ne osigurava na vrijeme lokomotive i vagone za prijevoz talijanskih postrojbi. Ravnateljstvo HDŽ-a u Sarajevu želi iz svojega

${ }_{93}$ HR-HDA-491-OUP, Broj: 2168/1941.

94 HR-HDA-491-OUP, Broj: 256/1942.

95 Zbornik dokumenata i podataka o NOR-u, tom XII, knj. 2, dok. br. 79.

96 Zbornik dokumenata i podataka o NOR-u, tom XII, knj. 2, dok. br. 94.

${ }_{97}$ Zbornik dokumenata i podataka o NOR-u, tom XII, knj. 2, dok. br. 144.

98 HR-HDA-491-OUP, Broj: 2080/1942. 
sjedišta organizirati željezničke transporte za talijanske potrebe, ali Sarajevo je predaleko od polaznih točaka tih transporta da bi se to moglo uspješno izvesti. Zato je od Ministarstva prometa NDH zatraženo neka poduzme korake da Ravnateljstvo HDŽ-a u Sarajevu više ne pravi poteškoće talijanskom Izaslanstvu za vojne transporte u Dubrovniku. ${ }^{99}$

Nakon što je o talijanskim žalbama obaviješteno Ravnateljstvo HDŽ-a u Sarajevu njegov ravnatelj Ante Vokić uputio je krajem lipnja 1942. Ministarstvu prometa u Zagrebu dopis u kojem je iznio žalbe na postupke talijanske vojske. Vokić je ponovio da su glavni problem za uredno odvijanje željezničkoga prometa upravo postupci talijanske vojske, koja svojom samovoljom i nedovoljnom organiziranošću unosi nered u promet. Talijani najprije naručuju vagone za svoje transporte, a zatim to otkazuju; na jednome mjestu zadržavaju vagone koji su potrebni upravo za prijevoz talijanske vojske na nekom drugome mjestu ili vagone, umjesto da ih stave na raspolaganje, koriste kao skladišta ili nastambe za svoje vojnike. Upravo se zbog tih razloga podjela vagona za transporte "paralizira”. Iako radnici HDŽ-a ulažu napore da zadovolje talijanske potrebe, izloženi su talijanskom neprijateljstvu i optužbama da su nesposobni i nelojalni. Zapravo je Ravnateljstvo HDŽ-a u Sarajevu, kada se uzme u obzir ograničeni vozni park kojim raspolaže, učinilo mnogo za potrebe talijanske vojske:

„[... proizlazi, da gotovo cijeli naš kolski park i vozna sredstva služe za prevoz u prvom redu talijanske, potom njemačke i u manjoj mjeri naše vojske. Za potrebe našeg civilnog pučanstva ne ostaje gotovo ništa zbog čega se je i stvorila neopisiva bijeda našeg pučanstva na jugu."100

Vokić je ocijenio da se stanje ne bi popravilo ni kada bi na raspolaganju stajao veći vozni park zbog opisanog „diletantskog” miješanja talijanske vojske u željeznički promet, koje šteti NDH, ali u konačnici i samim Talijanima. Također je objasnio da tehnički razlozi zahtijevaju da se raspodjela vagona usredotoči u Sarajevu. Kada bi se postupilo po talijanskim zahtjevima, cijeli bi vozni park Ravnateljstva HDŽ-a u Sarajevu trebalo prebaciti u obalni pojas, no to ne bi riješilo probleme, nego bi se stanje prometa dodatno pogoršalo. Stanje bi se popravilo, zaključio je Vokić, kada bi se Talijanima strogo zabranilo miješanje u uređenje prometa, ali je stvarna namjera Talijana onemogućiti djelatnost Ravnateljstva HDŽ-a u Sarajevu, odnosno da „prigrabe svu vlast nad željeznicama južno od Sarajeva". ${ }^{101}$

Nakon što je Ministarstvo prometa NDH primilo taj dopis proslijedilo ga je Talijanskoj kraljevskoj vojnoj misiji u Zagrebu s molbom da talijanska vojska prekine s miješanjem u prometno-tehničku službu HDŽ-a i da talijanske

${ }^{99}$ HR-HDA-219-MPJR NDH, Glavno ravnateljstvo za promet, Taj. Broj: 1374/1942.

${ }^{100}$ HR-HDA-219-MPJR NDH, Glavno ravnateljstvo za promet, Taj. Broj: 409/1942.

${ }^{101}$ Isto. 
pritužbe na rad HDŽ-a ubuduće budu konkretno obrazložene. ${ }^{102}$ Talijani su odgovorili sredinom listopada 1942. i uglavnom odbacili žalbe koje je iznio Vokić. Budući da je u međuvremenu u Dubrovniku uspostavljeno talijansko Izaslanstvo za vojne transporte, talijanska strana također je podsjetila da je zatražila da NDH i pri tom izaslanstvu osnuje svoj željeznički inspektorat. Njegovim osnivanjem, smatrali su Talijani, riješili bi se problemi na koje je upozoravalo Ravnateljstvo HDŽ-a u Sarajevu. ${ }^{103}$

Ravnateljstvo HDŽ-a u Sarajevu odgovorilo je tijekom studenoga 1942. Ministarstvu prometa NDH na talijanska stajališta. Rečeno je da su predstavnici toga ravnateljstva u međuvremenu održali sastanak s talijanskim Izaslanstvom za vojne transporte u Dubrovniku i tom prilikom postignuti su određeni rezultati, odnosno Talijani su izašli ususret pojedinim zahtjevima predstavnika HDŽ-a. Ravnateljstvo HDŽ-a u Sarajevu ipak je ponovilo da talijanska vojska mora shvatiti da se sa skromnim voznim parkom ne može „čudesa stvarati”. Zato je ponovno upozoreno da talijanska vojska ne smije odugovlačiti s utovarom i istovarom vagona kako bi se ti vagoni bolje iskoristili. Ostali problemi Ravnateljstva HDŽ-a u Sarajevu bili su kvarovi na ionako ograničenom voznom parku zbog prekomjernoga i neracionalnoga korištenja, kao i nedostatak materijala potrebnog za popravak. ${ }^{104}$

Krajem 1942. i početkom 1943. problema u odvijanju željezničkoga prometa između Sarajeva i Mostara bilo je i zbog nadzora koji su u postaji Bradina obavljali talijanski karabinjeri. Zbog njihova pregleda osobnih isprava, odnosno propusnica putnika pojedini su vlakovi kasnili i više od dva sata. Nakon brojnih žalbi koje su zbog toga upućene talijanskim predstavnicima oni su izjavljivali da će poduzeti potrebne mjere i da će karabinjeri pregledavati osobne isprave dok se vlakovi budu kretali između Konjica i Bradine. Unatoč tome žalbe HDŽ-a na kašnjenje vlakova zbog istoga razloga nastavile su se i početkom 1943. godine. ${ }^{105}$

Promet prugom Sarajevo - Mostar bio je poremećen tijekom operacije „Bijelo” koju su osovinske snage početkom 1943. izvele protiv glavnine partizanskih snaga koje su se nalazile u zapadnoj Bosni i okolnim područjima. Kada su se partizani povlačili preko Neretve, razorili su željezničke objekte i mostove na pruzi između Sarajeva i Mostara. ${ }^{106}$ Nakon tih događaja Zapovjedništvo 6. oružničke pukovnije u Mostaru izvijestilo je 10. lipnja 1943. da je željeznički promet Sarajevo - Mostar ograničen zbog prijevoza za potrebe njemačke vojske. Iz Mostara je u svakom vlaku za Sarajevo moglo putovati samo 25 civila. Stanovništvo je time bilo pogođeno jer nije moglo željeznicom

\footnotetext{
102 Isto.

${ }^{103}$ HR-HDA-219-MPJR NDH, Glavno ravnateljstvo za promet, Taj. Broj: 1271/1942.

${ }^{104}$ HR-HDA-219-MPJR NDH, Glavno ravnateljstvo za promet, Taj. Broj: 1563/1942.

105 HR-HDA-219-MPJR NDH, Glavno ravnateljstvo za promet, Taj. Broj: 1418/1942., Taj. Broj: 472/1943.; HR-HDA-491-OUP, Broj: 13.642/1942., Broj: 2591/1943.

106 Zbornik dokumenata i podataka o NOR-u, tom IV, knj. 11, dok. br. 343.
} 
putovati u „plodne krajeve naše države” da ondje nabavi hranu koju je zatim željeznicom dopremalo kući:

„Mostovi na Aleksinu Hanu i kod Jablanice sjeverno od Mostara, još nisu opravljeni i vrši se presjedavanje na tim mjestima. Od Aleksina Hana do Jablanice putuje se samovozima [Hrvatskih] državnih željeznica. Na ta dva mjesta moraju putnici po nekoliko dana čekati, dok ih dođe na red da sjednu u vlak i odputuju dalje. Na potezu Mostar-Dubrovnik, promet je normalan."107

Upravo tijekom lipnja 1943. domobranstvo je, u suradnji s njemačkom vojskom, na mostu kraj Jablanice počelo postavljati sklopivi most. ${ }^{108}$ Tako je ponovno uspostavljena i željeznička veza između Sarajeva i Mostara.

Nezgoda s posebnim vlakom zapovjednika 2. talijanske armije

Još jedan događaj povezan sa željezničkim prometom, iako ne od ključne važnosti, pokazuje spomenute nesuglasice između NDH i Talijana.

U kasnim poslijepodnevnim satima 4. svibnja 1943. na Glavni kolodvor u Zagrebu stigao je posebni talijanski vlak u kojem se nalazio zapovjednik 2. talijanske armije general Mario Robotti, koji je stigao u službeni posjet. Nakon toga osoblje HDŽ-a na Glavnom kolodvoru počelo je manevrirati tim vlakom, unatoč talijanskim prosvjedima, da bi na kraju vlak pri dovoženju na jedan od kolosijeka udario u odbojnik. Pri udaru su, kako su izjavili Talijani, svi njihovi ljudi u vlaku ozlijeđeni, a u vlaku je uništen dio opreme. Iz navedenih izvora nije sasvim jasno je li udar pretrpio i general Robotti ili je neposredno prije izašao iz vlaka. U svakom slučaju, Kraljevska talijanska vojna misija u Zagrebu ocijenila je da se radilo o namjernom propustu radnika HDŽ-a i zatražila da svi odgovorni za tu nezgodu budu kažnjeni, kao i da bude nadoknađena pretrpljena šteta. ${ }^{109}$

Ravnateljstvo državnih željeznica u Zagrebu ocijenilo je u izvješću od 19. svibnja 1943., nasuprot talijanskoj žalbi, da ne može biti riječ o težem prijestupu željezničara Glavnoga kolodvora u Zagrebu, a eventualna zla namjera u postupanju s vlakom zapovjednika 2. armije sasvim je odbačena. Ipak je ocijenjeno da se s takvim vlakom „visokoga ranga” trebalo postupati s više pažnje. Zato je odlučeno jednoga službenika smijeniti s položaja, kazniti ga odbitkom u iznosu od tri dnevne plaće, a dvojici je službenika zbog njihovih propusta izraženo „negodovanje”. ${ }^{110}$

No više vlasti NDH, Predsjedništvo Vlade i Ministarstvo prometa, to očito nisu smatrale dovoljnim. One su krajem svibnja i početkom lipnja 1943. od Glavnoga ravnateljstva za promet, odnosno Josipa Markovića, tražile da se

\footnotetext{
${ }^{107}$ HR-HDA-491-OUP, Broj: 5250/1943.

108 BARIĆ, Ustroj kopnene vojske domobranstva NDH, 189.

109 HR-HDA-491-OUP, Broj: 5428/1943.

${ }^{110}$ HR-HDA-219-MPJR NDH, Glavno ravnateljstvo za promet, Taj. Broj: 1943/1943.
} 
Talijanima nadoknadi šteta, ali i odgovorne službenike HDŽ-a primjerenije kazni zbog nezgode kojom je „osobno tangiran” general Robotti. Talijanima je trebalo pružiti zadovoljštinu i o tome obavijestiti Kraljevsku talijansku vojnu misiju u Zagrebu. Marković je odgovorio da su poduzeti koraci da se Talijanima nadoknadi šteta, a odgovorni službenici kažnjeni su upravnim mjerama, premještajem na druge dužnosti, a morali su i nadoknaditi dio štete. Marković je ocijenio da će te mjere odgojno djelovati i na ostale radnike HDŽ-a da ubuduće posvete više pažnje vlakovima „visokih dostojanstvenika”. Nedugo poslije Ravnateljstvo državnih željeznica u Zagrebu obavijestilo je Markovića o kaznama izrečenim službenicima odgovornim za nezgodu s vlakom generala Robottija. Jedan je kažnjen globom od 440 kuna i premješten na postaju Vinkovci, a drugi je sa zagrebačkoga Glavnoga kolodvora premješten na zagrebački Zapadni kolodvor. ${ }^{111}$

\section{Završna razmatranja}

Vidljivo je da je u načelno savezničkim odnosima Kraljevine Italije i NDH stvarnih nesuglasica i nepovjerenja bilo i kada je riječ o željezničkom prometu. Međusobno nepovjerenje izazvano talijanskom aneksijom hrvatskih obalnih krajeva nastavilo je rasti s talijanskim zaposjedanjem obalnoga pojasa i drugih dijelova NDH, kao i zbog talijanske suradnje s četnicima. Razumljivo, nije se radilo o ravnopravnom odnosu, nego o onome u kojem je snažnija talijanska strana mogla nametati svoja rješenja slabijem osovinskom partneru - ustaškoj $\mathrm{NDH}$.

Što se tiče željezničkoga prometa, opisani sukobi očitovali su se, primjerice, u težnji uprave HDŽ-a u Zagrebu da bude ukinut njezin inspektorat u Sušaku. Time bi Talijani u obalnom pojasu u vezi sa željezničkim prometom morali komunicirati izravno sa središnjim vlastima NDH u Zagrebu. No Talijani su očito težili imati „autonomni” Inspektorat HDŽ-a u Sušaku, kojem su mogli naređivati kako da upravlja prometom u obalnom pojasu. Talijani su tijekom 1942. tražili da HDŽ uspostavi i svoj inspektorat pri talijanskom Izaslanstvu za vojne transporte u Dubrovniku. Nisam naišao na podatke da je taj inspektorat osnovan.

Opisano je kako su Talijani na početku prihvatili da u Splitu, koji su anektirali, ostane osoblje i služba HDŽ-a, ali su od 1942. radili na tome da HDŽ bude uklonjen iz Splita, pri čemu su jednostrano preuzeli i željeznički promet u dijelovima Dalmacije koji su bili u sastavu NDH. Tu se „između redova” mogu iščitati i dublji uzroci međusobnoga neprijateljstva između Talijana i NDH. Naime, talijanska uprava u anektiranoj Dalmaciji nije željela da na njezinu području djeluju službenici NDH, odnosno njezini željezničari. To se opravdavalo time da se radi o suradnicima komunista, odnosno partizana. Nasuprot

111 HR-HDA-219-MPJR NDH, Glavno ravnateljstvo za promet, Taj. Broj: 2350/1943., Taj. Broj: 2743/1943. 
tome, predstavnici HDŽ-a težili su zadržati svoje osoblje u Splitu, čak i ako ono prijeđe u talijansku službu, jer bi to u određenom slučaju moglo koristiti NDH. Iako takve težnje u izvorima koje sam pregledao nisu bile jasno obrazložene, teško je izbjeći dojam da se pod time mislilo da bi ostanak željezničara HDŽ-a u Splitu mogao biti od neke koristi za NDH ako Rimski ugovori ipak budu poništeni i Split se eventualno vrati u sastav NDH.

Kada je riječ o održavanju željezničkih veza između obalnoga dijela NDH i zaleđa, one su bile ugrožene u prvom redu zbog diverzija i napada partizana. Pruga od Zagreba do Rijeke bila je izložena brojnim napadima, ali, prema dostupnim podacima, ipak je bila barem ograničeno otvorena za promet sve do kapitulacije Italije u rujnu 1943. godine. Nasuprot tome, Lička pruga također je bila izložena napadima partizana, ali je za promet potpuno prekinuta početkom 1943. nakon što se talijanska vojska povukla iz Like.

S obzirom na to da je pruga Zagreb - Rijeka bila važna za Talijane zbog transporta rumunjske nafte koji su tom prugom stizali u Italiju, oni su promet na njoj težili osigurati. Nasuprot tome, zbog talijanskih planova iz 1942. da se njihove snage povuku iz unutrašnjosti NDH i usredotoče na osiguranje krajeva anektiranih 1941., osiguranje prometa Ličkom prugom više nije bio prioritet za Talijane. Tu se očitovala slabost NDH. S jedne strane predstavnici NDH nisu bili zadovoljni talijanskim zaposjedanjem obalnoga pojasa. No kada je, primjerice u Lici, došlo do povlačenja talijanskih snaga, NDH bez njih nije bila u stanju zadržati nadzor nad tim područjem, nego su njime brzo ovladali partizani.

Uskotračnom prugom od Broda na Savi i Sarajeva prema Mostaru i Dubrovniku promet se, unatoč problemima, odvijao sve do početka 1943., kada je u ratnim događajima porušen željeznički most kraj Jablanice. No ta pruga ponovno je uspostavljena.

Sa svim opisanim problemima vlasti u Zagrebu postupno su veću važnost davale mogućnosti da se promet prema obalnom pojasu obavlja željeznicom do Sušaka-Rijeke, zatim brodovima do luka u obalnom pojasu ili anektiranoj Dalmaciji i zatim iz njih prema unutrašnjosti obalnoga pojasa. Već krajem prosinca 1941. predstavnici NDH zahtijevali su da se stanovništvo obalnoga pojasa opskrbljuje hranom na taj način. ${ }^{112}$

Nedugo potom, početkom 1942., postavilo se pitanje opskrbe Glamoča hranom. Predstavnici NDH smatrali su da bi talijanska vojska trebala osigurati željezničku prugu „Šipada” od Prijedora do Jajca da bi njome bili opskrbljeni Glamoč, kao i Livno i Tomislavgrad. No Talijani su smatrali da bi hranu bilo bolje iz unutrašnjosti dopremiti do Sušaka, zatim brodovima do Splita ili Šibenika, pa iz tih luka kopnom prema spomenutim mjestima. ${ }^{113}$ Slično tome, Poslanstvo Kraljevine Italije navelo je početkom 1942. u dopisu Ministarstvu vanjskih poslova NDH da je talijanska vlada poduzela mjere da se poboljša

\footnotetext{
${ }^{112}$ HR-HDA-491-OUP, Broj: 384/1942.

113 HR-HDA-491-OUP, Broj: 1296/1942.
} 
opskrba Dubrovnika i okolice hranom tako što je odredila da se luka u Rijeci koristi za dopremu hrane na to područje morem. ${ }^{114}$

Sredinom srpnja 1942. vlasti u Zagrebu smatrale su da bi zbog prekida na željezničkoj pruzi od Sarajeva do Mostara poštanski promet za dio Dalmacije koji je bio u sastavu NDH i za Hercegovinu trebalo preusmjeriti na Sušak, odakle bi se pošta brodovima dopremala do odredišta. Zapovjedništvo 2. talijanske armije smatralo je da bi se poštanski promet za te dijelove NDH mogao odvijati željeznicom kroz Liku. Ako se to ne drži mogućim, vlasti NDH trebale su se vezano uz taj prijedlog obratiti središnjim talijanskim vlastima u Rimu nadležnima za poštanski promet. ${ }^{115} \mathrm{Ne}$ raspolažem izvorima kako je to pitanje riješeno.

Početkom 1943., po talijanskom napuštanju Ličke pruge i Gračaca i s obzirom na činjenicu da su na području doline Neretve vođene borbe partizana i osovinskih snaga, vlasti NDH u središnjoj Dalmaciji mogle su izvijestiti pretpostavljene da su se našle u potpunoj prometnoj blokadi. Tako je 6. ožujka 1943. Domobransko popunidbeno zapovjedništvo u Kninu izvijestilo da je prekinut željeznički promet kroz Liku, ali i kroz Bosnu, pa je onemogućen „svaki promet”. 116 Slično tome, Zapovjedništvo oružničkoga krila u Omišu izvijestilo je početkom travnja 1943. da je stanje prehrane na njegovu području vrlo slabo, a to se dodatno pogoršalo prekidom prometa željeznicom od Sarajeva do Mostara. ${ }^{117}$

Zapovjedništvo 2. oružničke pukovnije u Gospiću sa svoje je strane sredinom lipnja 1943. konstatiralo da je željeznički promet kroz Liku prekinut, ali je pruga od Zagreba i Karlovca do Rijeke ipak u prometu:

„Željezničke i druge prometne veze su od strane partizana veoma ugrožene. Na dielu željezničke pruge Ogulin - Knin već duže vremena prekinut je svaki promet, a na dielu Ogulin - Plase održava se sa veoma velikim poteškoćama."118

Kako se dio prometa usmjeravao prema Sušaku-Rijeci, NDH je ondje našla otpremnike koji su se brinuli za daljnji prijevoz transporta. U ljeto 1942. otpremom kukuruza koji je iz unutrašnjosti poslan za opskrbu Dalmacije bavio se otpremnik Albert Katić, koji je imao poduzeće u Sušaku-Bakru. ${ }^{119}$

Opće upravno povjereništvo NDH u Sušaku imalo je početkom 1943. kao svojega ugovornog prijevoznika i Vazmoslava Pavešića, koji je u Sušaku imao poduzeće Odprema. On je primao vojnike NDH, opremu i hranu koja

\footnotetext{
114 HR-HDA-491-OUP, Broj: 4199/1942.

115 HR-HDA-491-OUP, Broj: 7554/1942.

116 HR-HDA-491-OUP, Broj: 4556/1943.

117 Narodnooslobodilačka borba u Dalmaciji 1941-1945. Zbornik dokumenata, knj. 6, dok. br.

118 HR-HDA-491-OUP, Broj: 5377/1943.

119 HR-HDA-491-OUP, Broj: 8360/1942.
} 278. 
je stizala željeznicom u Sušak-Rijeku, a zatim ih je uz pomoć talijanske vojske brodovima otpremao prema odredištu: Senju, Gospiću, Kninu i Sinju. ${ }^{120} \mathrm{Na}$ isti se način promet odvijao i u suprotnom smjeru. Primjerice, kada je u ljeto 1943. trebalo otpremiti skupinu od 140 hrvatskih izbjeglica s područja Sinja u Slavoniju, između Talijana i vlasti NDH dogovoreno je da će oni iz Splita biti prebačeni u Rijeku parobrodom, a zatim vlakom do Zagreba. ${ }^{121}$

Željezničke prometnice koje su povezivale obalni pojas NDH sa zaleđem postupno su bivale sve ugroženije zbog djelovanja partizana. Nakon kapitulacije Kraljevine Italije i promjena do kojih je to dovelo na području NDH željezničke veze obalnoga pojasa NDH sa zaleđem našle su se u još slabijem stanju. Lička pruga ostala je prekinuta, a nakon talijanske kapitulacije, po svemu sudeći, iz prometa je sasvim ispala i pruga Zagreb - Rijeka. Promet iz Zagreba, odnosno iz dijelova NDH sjeverno od Save, odvijao se željeznicom preko Ljubljane do Rijeke-Sušaka i zatim brodovima do luka na jadranskoj obali. Druga komunikacija bila je željezničkom prugom Zagreb - Bosanski Novi - Bihać, a zatim konvojima kamiona do Knina. Tako je jedina željeznička veza ostala bosanska uskotračna pruga, kojom se promet nastavio odvijati. ${ }^{122}$

\section{Arhivski izvori}

HR-HDA: Hrvatska, Hrvatski državni arhiv, Zagreb:

fond 219-MPJR NDH: Ministarstvo prometa i javnih radova Nezavisne Države Hrvatske.

fond 241-RDŽ: Ravnateljstvo državnih željeznica Zagreb.

fond 250-UV: Ustaška vojnica.

fond 491-OUP: Opće upravno povjereništvo NDH kod II. armate talijanske vojske / Višeg zapovjedništva talijanskih oružanih snaga „SlovenijaDalmacija"

\section{Objavljeni izvori}

Narodnooslobodilačka borba u Dalmaciji 1941-1945. Zbornik dokumenata, knj. 2: Siječanj - srpanj 1942. godine. Split: Institut za historiju radničkog pokreta Dalmacije, 1982.

Narodnooslobodilačka borba u Dalmaciji 1941-1945. Zbornik dokumenata, knj. 6: Travanj - lipanj 1943. godine. Split: Institut za historiju radničkog pokreta Dalmacije, 1984.

Zbornik dokumenata i podataka o Narodnooslobodilačkom ratu naroda Jugoslavije, tom IV (Borbe u Bosni i Hercegovini), tom V (Borbe u Hrvatskoj),

\footnotetext{
120 HR-HDA-491-OUP, Broj: 3941/1943.

121 HR-HDA-491-OUP, Broj: 6453/1943.

122 Opširno o tome vidi: BARIĆ, Ustaše na Jadranu, 584-602.
} 
tom XII (Dokumenti Nemačkog Rajha), tom XIII (Dokumenti Kraljevine Italije). Beograd: Vojnoistorijski institut, 1955.-1976.

\section{Literatura}

BARIĆ, Nikica. Ustaše na Jadranu. Uprava Nezavisne Države Hrvatske u jadranskoj Hrvatskoj nakon kapitulacije Kraljevine Italije. Zagreb: Hrvatski institut za povijest, 2012.

BARIĆ, Nikica. Ustroj kopnene vojske domobranstva Nezavisne Države Hrvatske, 1941. - 1945. Zagreb: Hrvatski institut za povijest, 2003.

JELINOVIĆ, Zvonimir. Borba za jadranske pruge i njeni ekonomski ciljevi. Zagreb: Jugoslavenska akademija znanosti i umjetnosti, 1957.

KISIĆ KOLANOVIĆ, Nada. NDH i Italija. Političke veze i diplomatski odnosi. Zagreb: Naklada Ljevak; Hrvatski institut za povijest, 2001.

LAJNERT, Siniša. „Ustroj Hrvatskih državnih željeznica (1941-1945)”. Arhivski vjesnik 46 (2003), br. 1: 101-129.

LEKOVIĆ, Mišo. „Reagovanje Italijana na ustanak u Bosni i Hercegovini (reokupacija Demilitarizovane zone)". U: 1941. u istoriji naroda Bosne i Hercegovine. Naučni skup održan u Drvaru od 7. do 9. oktobra 1971. godine. Sarajevo: Izdavačko preduzeće „Veselin Masleša”, 1973, 466-484.

MARIJAN, Davor. „Ustaške vojne postrojbe 1941. - 1945.” Magistarski rad, Sveučilište u Zagrebu, 2004.

NENEZIĆ, Dragan S. Jugoslovenske oblasti pod Italijom 1941-1943. Beograd: Vojnoistorijski institut Vojske Jugoslavije, 1999.

ORLOVIĆ, Đorđe. Šesta lička proleterska divizija „Nikola Tesla”. Beograd: Vojnoizdavački i novinski centar, 1990.

POPOVIĆ, Jovica; BJELOBABA, Milan. „Općina Gračac u razdoblju od 1918. do aprila 1942. godine”. U: Kotar Gračac u narodnooslobodilačkom ratu 1941-1945., knj. 1. Karlovac: Historijski arhiv u Karlovcu, 1984, 316-363.

TOMASEVICH, Jozo. War and Revolution in Yugoslavia, 1941-1945: Occupation and Collaboration. Stanford, California: Stanford University Press, 2001. 


\section{SUMMARY}

\section{Railway Lines in the Coastal Belt of the Independent State of Croatia until the Fall of Kingdom of Italy}

The paper presents the state of railway traffic in the coastal belt of the Independent State of Croatia (Nezavisna Država Hrvatska, NDH) and the railway lines that connected that area with Zagreb and the rest of the NDH. These lines were the Zagreb-Rijeka (Fiume) line, the Lika line from Zagreb to Split, and the Bosnian narrow gauge line from Brod na Savi via Sarajevo to Mostar and Dubrovnik. In early September 1941, the Italian army took over command of the civilian and military NDH authorities in the coastal zone, and accordingly over the rail lines in that area. Relations between the NDH and Kingdom of Italy were formally those of close alliance and cooperation. In reality, however, the fact that the Italians annexed certain parts of Croatian coastal territory in May 1941 as well as the Italian occupation of the coastal zone caused mutual distrust and disagreements between the Italians and the NDH regime. Such relations were also visible in the railway traffic, where Italians often assumed command and control without consulting the Croatian State Railways.

Already during late 1941, the Partisan movement directed its attacks on railway communications. Partisans committed hundreds of attacks on railway and trains, and soon traffic was heavily disrupted and limited on all railway lines connecting the coastal belt with Zagreb and the hinterland. In early 1943, Italian troops withdrew from Lika, and Partisans quickly took control over that region. After that, the Lika railway from Zagreb to Dalmatia was cut, and it did not become operational until after the war. After the Italian armistice with the Allies and the disintegration of Italian troops in the NDH and areas annexed in 1941, the Zagreb-Rijeka line was also cut. Only the Bosnian narrow gauge line remained operational as a link between the coastal parts of the NDH and its hinterland. In fact, because of the attacks on other railway lines, already from late 1941 the $\mathrm{NDH}$ authorities were redirecting the traffic to the Zagreb-Rijeka line (or Zagreb-Ljubljana-Rijeka line), and transports that arrived to Rijeka were then shipped by sea to ports in the Croatian Littoral and Dalmatia.

Key words: Independent State of Croatia (NDH); Ministry of Communications and Public Works of the NDH; Croatian State Railways; Royal Italian Army; railway traffic 